\title{
Towards Complexity and Dynamics: A Bibliometric-Qualitative Review of Network Research in Construction
}

\author{
Dongping Cao $i$ and Shiting Shao $(i)$ \\ Department of Construction Management and Real Estate, School of Economics and Management, Tongji University, \\ Shanghai 200092, China \\ Correspondence should be addressed to Shiting Shao; shiting_shao@tongji.edu.cn
}

Received 18 September 2020; Revised 17 November 2020; Accepted 21 November 2020; Published 14 December 2020

Academic Editor: Guangdong Wu

Copyright (c) 2020 Dongping Cao and Shiting Shao. This is an open access article distributed under the Creative Commons Attribution License, which permits unrestricted use, distribution, and reproduction in any medium, provided the original work is properly cited.

\begin{abstract}
Social network analysis (SNA) has gained increasing academic attention in the construction domain over the past two decades due to its capability to characterize the complexity and dynamics of interindividual and interorganizational interactions. To date, however, scant attempt has been made to develop an integrated framework to systematically review the diversified network research at different levels in this domain and to quantitatively characterize the evolution of related research interests and research instruments. This study aims to fill this gap by conducting a bibliometric-qualitative review based on 106 papers published from 1997 to 2020. Keyword cooccurrence analysis is employed to reveal the research foci, identify the research trends, and develop a comprehensive categorization framework, which classifies related research based on two interrelated dimensions: the type of network node (individual and organization) and the levelof network analysis (project level, corporate level, and industry level). The framework then facilitates further content analysis in terms of research topics, research designs, and research instruments. The results provide evidence that the research foci in this domain are generally moving towards addressing the complexity and dynamics of project-related relations at more diversified levels, in terms of not only research topics but also research instruments. Future research can be enriched by investigating the multiple types of dynamic interproject relationships, adopting state-of-theart methodologies for network data collection and triangulation, and employing multiple SNA constructs and inferential statistical methods to reveal how complex networks coevolve and interact with actors' behaviors as well as project and organizational outcomes.
\end{abstract}

\section{Introduction}

As a pillar industry in many countries, the construction industry is a typical project-based sector within which production and business activities are generally organized based on temporary and multiorganizational projects $[1,2]$. From a short-term perspective, multiple individuals and organizations from diversified disciplines need to closely interact with each other within a project [3-6], thus forming complex intraproject communication and collaboration networks that have the potential to substantially influence project activities and performance [7, 8]. From a long-term perspective, with the initiation and accomplishment of different construction projects, individuals and organizations will further form evolving and complex interproject relationship networks at the corporate and industry levels $[3,9,10]$, which also closely relate to how information and knowledge diffuse among different individuals and organizations across projects. As such, relationship networks developed in the construction industry not only demonstrate unique complexity features in terms of multiplex network levels, diversified network actors, and manifold relationship types [3, 11], but also exhibit distinct dynamic characteristics with the initiation and accomplishment of different temporary projects $[3,12]$.

With the increasing complexity and dynamics of construction projects, multiple approaches have been used to solve complex and dynamics problems in the construction domain, such as system dynamics, agent-based modeling, and social network analysis (SNA) [6, 13-17]. As a 
theoretical lens that focuses on relational structures rather than self-reliant actors [18], SNA has been increasingly used to characterize interindividual or interorganizational relationship networks in the construction domain since the early work of Loosemore [19] around 1997. In consideration of the increase and significance of network research in the construction domain, previous studies have attempted to summarize the application of SNA in construction research from specific perspectives. By qualitatively tracing the development of SNA research from 1997 to 2011, Chinowsky and Taylor [16] proposed an insightful path forward for future network research in the project organization domain. Zheng et al. [17] conducted a thorough review of the SNA application in the construction project management domain and identified eight main research interests using keyword cooccurrence analysis. Lee et al. [6] qualitatively reviewed 65 papers to discuss the applications of SNA constructs in the complex project management domain. Despite the multiplex levels and manifold relation types of networks in construction, however, scant scholarly attention has been devoted to developing an integrated framework for the network research in the construction domain and providing a systematic view of related research at different levels. Such a framework could not only help to more comprehensively identify research topics, research instruments, and research gaps of extant research as well as potential directions for future research, but also contribute to deepened understandings of the complexity and dynamics inherent in the relationship networks in the construction domain.

This study aims to address this gap by conducting a bibliometric-qualitative review of the network research in the construction domain to systematically map and categorize the research areas, graphically illustrate the evolution of research interests and research instruments, and identify potential directions for future research. Bibliometric analysis is employed to identify the research foci and trends in network research and reorganize the research into a categorization framework to help researchers comprehensively comprehend the research areas in the construction domain. The framework will facilitate further content analysis in terms of research topics, research designs, and research instruments. The next section of this paper contains an introduction to the research methods concerning data retrieval processes, bibliometric analysis, and content analysis. The subsequent section summarizes the findings. The final section draws upon the findings to discuss the main implications and future research directions.

\section{Research Methodology}

A "mixed-methods systematic review," termed by Harden and Thomas [20], which combines quantitative and qualitative synthesis approaches was used in this study. A traditional systematic review is an effective method to produce a rigorous summary of the literature findings, map out gaps in the research, and guide future research [21]. However, outcome reporting bias may be introduced, and the interpretation of results is prone to be subjective in a manual review [22]. Therefore, a mixed-methods systematic review that combines bibliometric analysis and content analysis is needed to scientifically identify the knowledge base and evolution of a topic [23]. Figure 1 displays the research design of this study. The following subsections will provide details of each stage as shown in Figure 1.

2.1. Data Retrieval Process. To retrieve elaborated SNAbased publications, this study not only adopted the review methods widely employed in the construction domain $[17,24]$, but also conducted a forward search to ensure the comprehensiveness of the search results. First, a comprehensive database search was conducted in the title/abstract/ keyword field of Scopus. Scopus was selected due to its wider coverage of publications in the construction domain as compared to other databases such as Web of Science [25-27], which does not fully cover the Emerging Sources Citation Index (ESCI) journals such as Journal of Management in Engineering (JME). Search keywords included "social network," "project network," "network structure," "network theory," "organization network," "network analysis," "SNA," and "stakeholder network." Similar keywords were widely used in previous research [28]. The truncation symbol $(*)$ was also used to retrieve variations of the search keywords [29]. The search was limited to areas including "computer science," "engineering," "social science," "business, management, and accounting," "environment science," "decision sciences," and "energy." Only publications with "article" as the document type were included. The search code is as follows.

TITLE-ABS-KEY ("social network * " OR "project network * " OR "network structur * " OR "network theory" OR "organization * network *" OR "network analysis" OR sna OR "stakeholder network *") AND (LIMIT-TO ( SUBJAREA, "COMP") OR LIMIT-TO (SUBJAREA, "ENGI") OR LIMIT-TO (SUBJAREA, "SOCI") OR LIMIT-TO (SUBJAREA, "BUSI") OR LIMIT-TO (SUBJAREA, "ENVI") OR LIMIT-TO (SUBJAREA, "DECI") OR LIMIT-TO (SUBJAREA, "ENER") OR LIMIT-TO (SUBJAREA, "ECON")) AND (LIMIT-TO (DOCTYPE, “ar")) AND (LIMIT-TO (LANGUAGE, "English")) Search result: 104,203 (Searched on 29 June 2020)

Noting that a certain proportion of irrelevant papers were present in the results, the target journals were further limited to refine the search. Seven top-ranked journals were selected according to the ranking list of Chau [30]: Construction Management and Economics (CME), Journal of Construction Engineering and Management (JCEM), Engineering, Construction and Architectural Management (ECAM), Journal of Management in Engineering (JME), International Journal of Project Management (IJPM), Automation in Construction (AIC), and Building Research and Information (BRI). These journals are impactful in the construction domain and have published the most SNArelated publications as indicated by previous studies [17]. Additionally, two other peer-reviewed journals-Engineering 


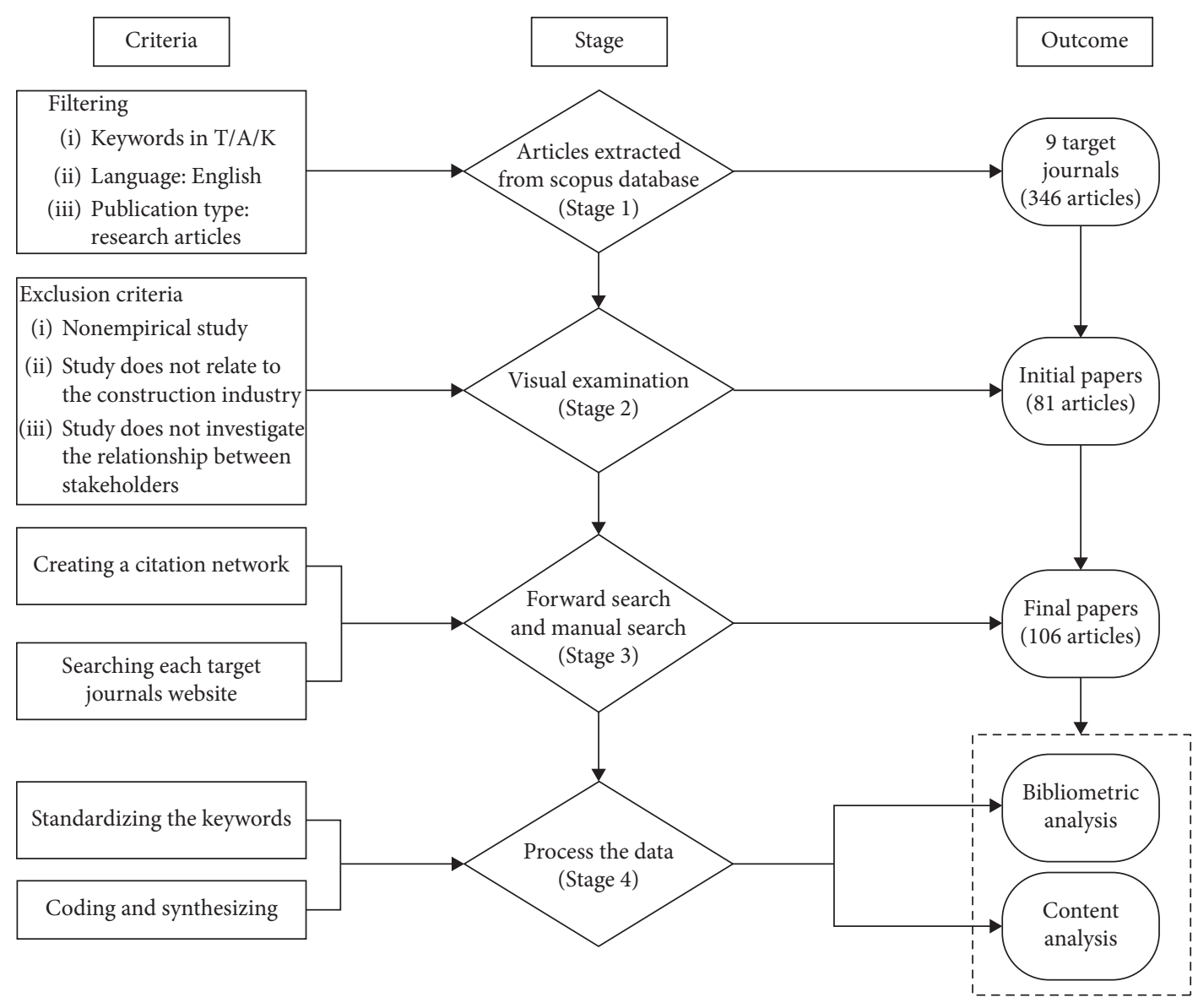

Figure 1: Research design.

Project Organization Journal (EPOJ) and Project Management Journal (PMJ)-were also included in the target journal list because they have published frequently cited SNA-based research and are regarded as qualified sources to capture papers in the construction domain [17]. As a result, a total of 346 articles were identified in Stage 1.

In Stage 2, a visual examination of the paper contents was conducted. An article was regarded as relevant if it met the following three criteria: (1) it focuses on empirical research, (2) it is related to the construction domain, and (3) it investigates the relationships between individuals or organizations. The initial selection results (listed in Table 1) revealed that Scopus did not contain the journal EPOJ. Moreover, Scopus did not have full records of some other selected journals $[17,24]$. This necessitated the combination of a database search and other supplementary search strategies.

In Stage 3, a forward search and a manual search were conducted to ensure the comprehensive coverage of SNAbased publications. These strategies can help further identify those papers that might be omitted by the former database search [31]. A citation network containing articles that cited the initial 81 papers was created in Scopus. As a result, a total of 370 articles were found from the selected journals. After scanning these papers by reading the titles and abstracts, no additional publication was identified, which verified the comprehensiveness of the database search result. Considering that Scopus did not have full records of the selected journals, a manual search was further carried out. Through searching the websites of all the target journals, 25 additional papers were found, as shown in Table 1. Finally, a total of 106 publications released from 1997 to 2020 were identified. Figure 2 displays the distribution of these studies in 1997-2020. It is evident that the number of publications rapidly increased from 1997 to 2011 and significantly surged in 2017.

2.2. Bibliometric Analysis. Bibliometric analysis refers to visualizing, exploring, and analyzing large-scale historical data from an objective and quantitative perspective [32]. It helps identify the intellectual base of a scientific area and the evolution of research topics [33, 34]. CiteSpace Version 5.5.R2 was used in this study. This software enables researchers to explore both intellectual bases and research fronts within the same time-variant mapping [35].

The SNA-based research (1997-2020) dataset consisted of 81 records extracted from the Scopus database and 25 records added manually. The terms extracted from the title, abstract, and author keywords were used as analytical units as they are regarded as concise and comprehensive descriptions of the research contents [22]. Following data 
TABLe 1: Number of identified publications in the targeted journals.

\begin{tabular}{lcc}
\hline Journal titles & Number of papers (initial selection) & Number of papers (final selection) \\
\hline Journal of Construction Engineering and Management & 27 & 31 \\
Construction Management and Economics & 16 & 19 \\
Journal of Management in Engineering & 11 & 15 \\
International Journal of Project Management & 8 & 10 \\
Automation in Construction & 7 & 7 \\
Project Management Journal & 6 & 7 \\
Engineering Construction and Architectural Management & 4 & 5 \\
Building Research and Information & 2 & 3 \\
Engineering Project Organization Journal & 0 & 9 \\
Total & 81 & 106 \\
\hline
\end{tabular}

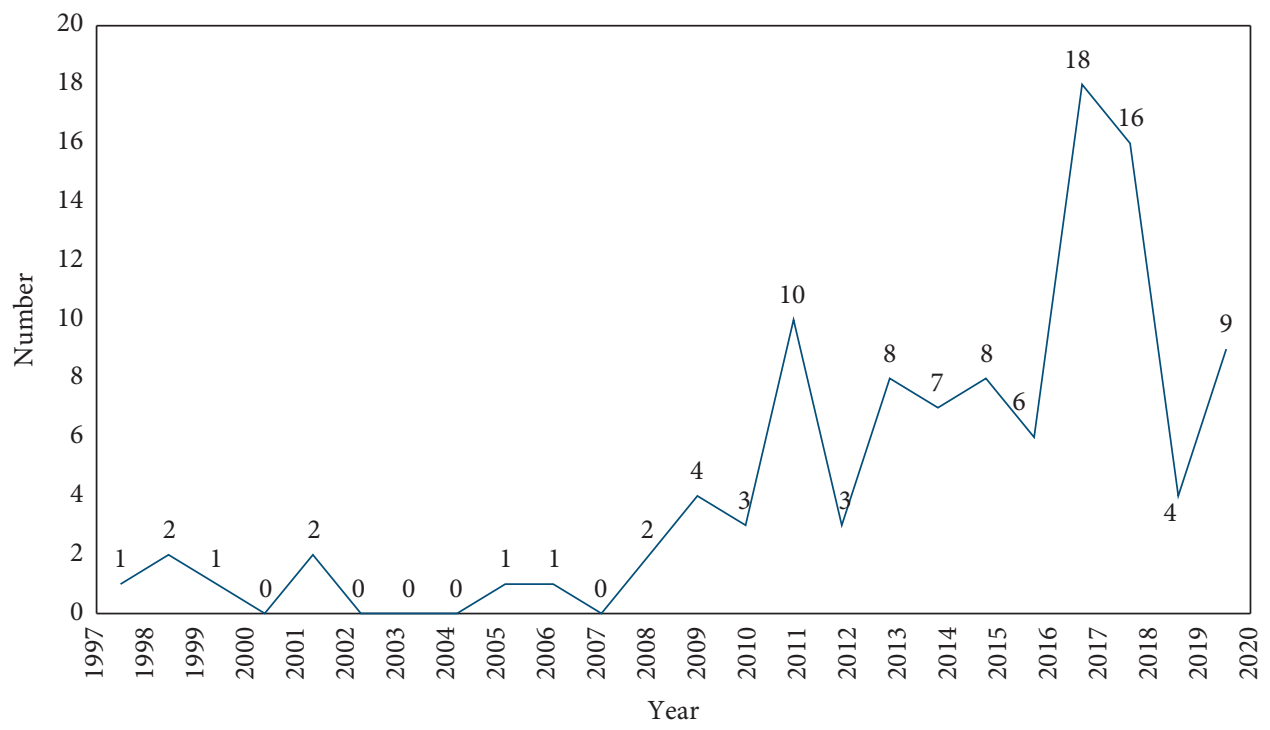

FIgURE 2: Number of identified publications from 1997 to 2020.

acquisition, data processing is also considered an important part of bibliometric analysis [22]. Noting the differences in several similar terms, keywords such as "building information modeling," "building information modelling," "BIM," and "building information modeling (BIM)" were all standardized as "building information modeling." Keywords that did not add value to this study were excluded, such as "case study," "conceptual framework," "providing insight," "new understanding," "propositional theoretical model," and "anecdotal evidence." After data processing, keyword cooccurrence analysis was employed in both cluster view and time-zone view which will be illustrated in detail in subsequent sections.

2.3. Content Analysis. Content analysis is generally employed to capture the presence of crucial content and elicit meanings of the content [36]. Table 2 shows the codebook employed to code the selected papers. Variables were collected to capture information at three levels: research topics, research designs, and research instruments. Data at the research topics level included the categories of network analysis and types of network relations. Data at the research designs level included boundary specification methods and data collection methods. Data at the research instruments level included SNA constructs (such as degree centrality, betweenness centrality, closeness centrality, and network density) and quantitative analysis methods.

Two coders independently coded the 106 studies. For all variables but two (types of network relations and quantitative analysis methods), Cohen's kappa [44] was employed to measure the interrater reliability (IRR) as it is a commonly used statistic for nominal variables. The IRR of types of network relations and quantitative analysis methods were measured based on the percent agreement as multiple relationships and methods were involved in several studies; the values obtained were 0.972 and 0.926 for types of network relations and quantitative analysis methods, respectively. Using the syntax provided by Hallgren [45], Cohen's kappa was computed in SPSS 23. For each variable, Cohen's kappa ranged from 0.824 to 1 , with a mean value of 0.881 , indicating perfect agreement between the coders [46]. The IRR of the collected variables is shown in Table 2. The final round of coding was carried out by one coder to resolve the disagreements between the two former coders. 
TABLE 2: Description and interrater reliability of collected variables.

\begin{tabular}{|c|c|c|}
\hline Variables & Descriptions & IRR \\
\hline \multicolumn{3}{|c|}{ Research topics } \\
\hline $\begin{array}{l}\text { Categories of network } \\
\text { analysis }\end{array}$ & Categorization of network research according to the type of node and the level of analysis & 0.894 \\
\hline Types of network relations & $\begin{array}{c}\text { Communication network, information and knowledge sharing network, collaboration network, etc. } \\
\text { Research designs }\end{array}$ & 0.972 \\
\hline $\begin{array}{l}\text { Boundary specification } \\
\text { methods }\end{array}$ & Exogenously defined, relationally defined, and methodologically defined & 0.864 \\
\hline Data collection methods & $\begin{array}{l}\text { Survey and interview, databases, mixed, and others } \\
\text { Research instruments }\end{array}$ & 0.915 \\
\hline Degree centrality & The number of direct links with others [37] & 0.853 \\
\hline Betweenness centrality & The extent to which a node falls on the geodesic paths between others [38] & 0.830 \\
\hline Closeness centrality & The ease of connection from a node to all other nodes [38] & 0.933 \\
\hline Eigenvector centrality & The number of links weighted by the centrality of the connectors [39] & 0.827 \\
\hline Structure hole & The lack of a direct relation between two nonredundant cliques [40] & 0.824 \\
\hline Structural equivalence & The extent to which two nodes share the same pattern of relations [41] & 1.000 \\
\hline Network density & The extent of the connectivity of a network [42] & 0.887 \\
\hline Network cohesion & The extension of relational cohesion in the network level [42] & 0.827 \\
\hline $\begin{array}{l}\text { Power-law degree } \\
\text { distribution }\end{array}$ & $\begin{array}{l}\text { The so-called "scale-free" property indicates few nodes having many links and many nodes having } \\
\text { few links [43] }\end{array}$ & 0.918 \\
\hline $\begin{array}{l}\text { Quantitative analysis } \\
\text { methods }\end{array}$ & Descriptive analysis, correlation analysis, regression analysis, simulation analysis, and others & 0.926 \\
\hline
\end{tabular}

Note: IRR in bold is measured based on percent agreement.

\section{Results}

3.1. Results of Keyword Cooccurrence Analysis. In this study, the keyword cooccurrence network was derived from the 50 most-cited items in a four-year time interval, ranging from 1997 to 2020. This resulted in a network of 143 nodes with 509 links connecting them, as visualized in Figure 3. The size of a node represents how frequently a term appears in the dataset. The thickness of a link indicates the frequency with which the two terms cooccur. The colors of these links-purple, blue, cyan, green, yellow, and red-correspond to different time slices from 1997 to 2020. The colors of these lines are determined by the first time the two terms were used together.

The network displayed in Figure 3 illustrates the intellectual base and main foci in SNA-based research. Keywords such as "organizational issue," "project-based organization," "project organization," "organizational structural," and "project team" occupied salient positions in the network. This indicates that network studies in the construction domain involve different types of focal actors and that both interindividual and interorganizational relationships were investigated in the literature, which is consistent with the conclusion of Chinowsky and Taylor [16]. Figure 3 also shows that communication, knowledge sharing, and collaboration were the most frequently investigated relationships in the construction literature.

As keyword cooccurrence analysis in the cluster view only displays a static figure [22], the cooccurrence network was further employed in the time-zone view to illustrate the evolution of research interests and identify the research frontiers [35]. As shown in Figure 4, the size of a node represents the degree centrality of a term, the lines

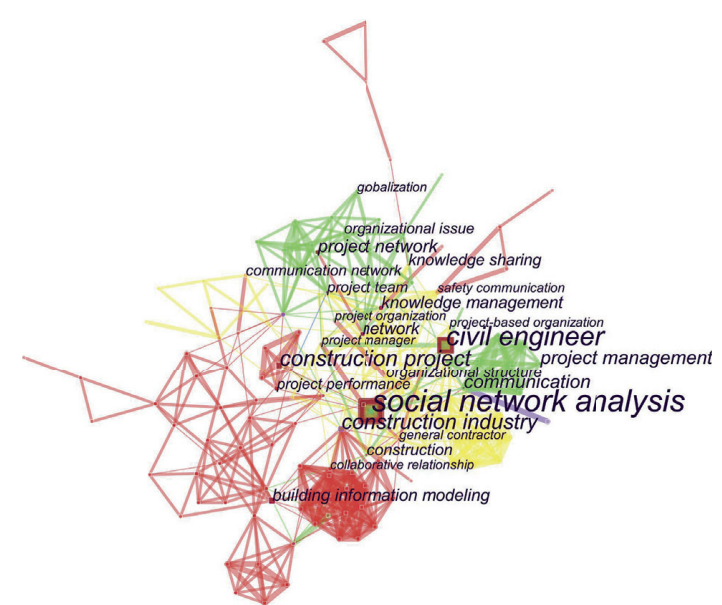

Figure 3: Keywords cooccurrence network (1997-2020).

link the keywords used together, and the colors of these lines represent the time a connection occurred for the first time. Early research tended to focus on communications within project teams, as suggested by the dominance of keywords "communication" and "project team" in the network literature before 2005. Increasing interests have been gathered around "knowledge management" and "cultural boundary issue" since 2009. From 2013 to 2016, "safety," "performance," and "small work crew" became the primary research keywords, which might illustrate an emphasis on addressing more specific problems such as safety management and performance improvement in the network research during this stage. Since 2017, increasing research interests have been emerging on "industry organization," "project-based collaborative network," and "industry-level network". This result tends to suggest that 


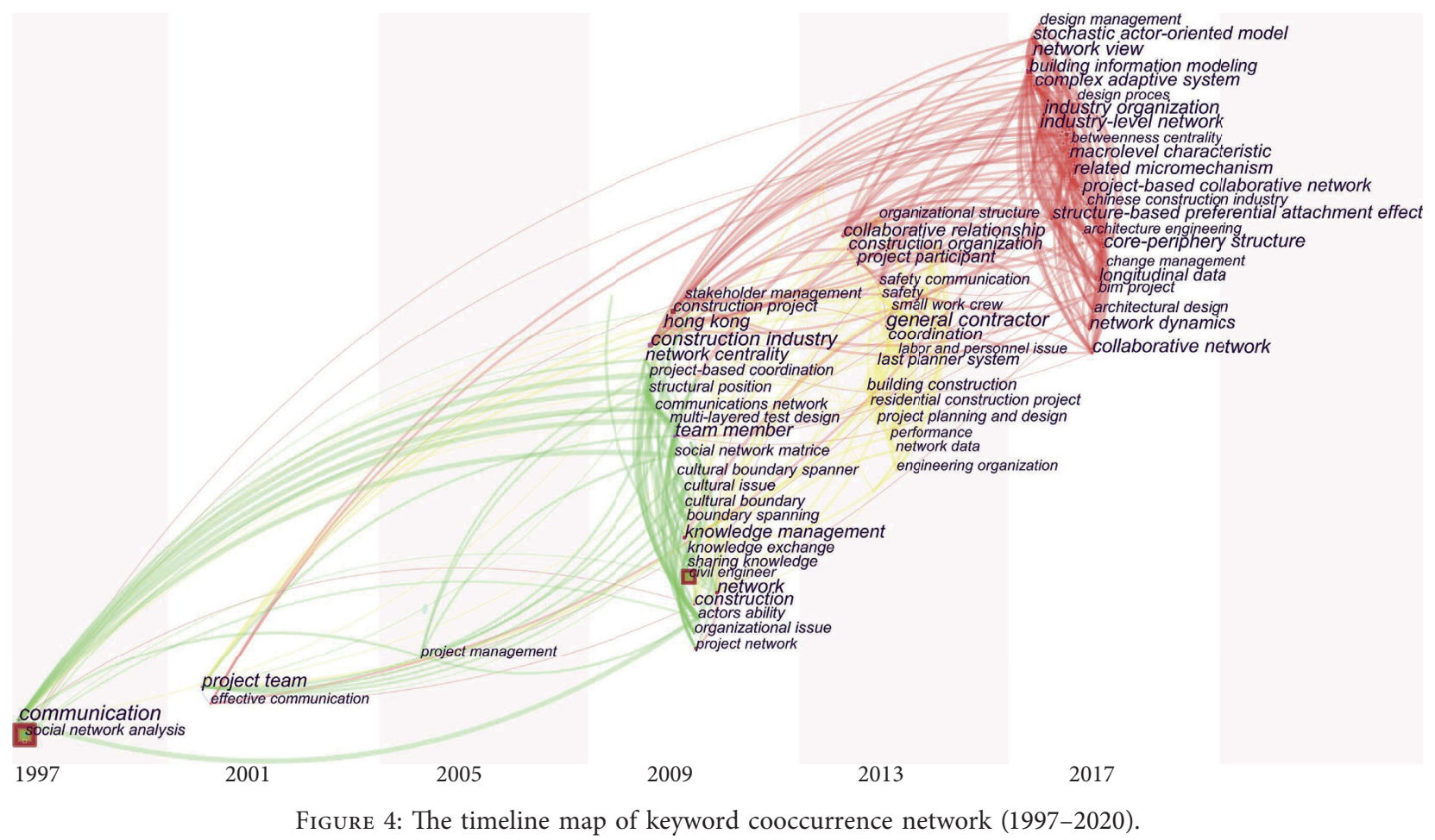

while a large amount of early studies related to networks in construction have focused on examining interindividual or interorganizational relationships within a single construction project $[19,47-50]$, industry-level relationships across different project contexts began to elicit growing interests in recent years $[3,9,11,51-53]$. It is also evident from Figure 4 that dynamics-related keywords such as "complex adaptive system," "stochastic actororiented model," "longitudinal data," and "network dynamics" distinctly emerged in the keyword cooccurrence network since 2017, suggesting that related research have begun to veer away from a static focus to a dynamic perspective. Taken together, these results provide evidence that research foci of network studies in the construction domain are evolving from simple and statistic networks towards the complexity and dynamics of relationship networks at more diversified levels, which is closely related to the variety of participants and the temporary nature of their collaborative relationships in the construction industry.

The results further indicate that the SNA-based research conducted in the construction domain can be placed into a categorization framework with two dimensions (see Table 3). The first dimension, the type of network node, identifies whether the research was focused on relationships among individuals or among organizations. The second dimension, the level of network analysis, reflects whether the relationships were analyzed at the project level, corporate level, or industry level. It is worth-noting that the results of keyword cooccurrence analysis can be misinterpreted out of context [22], necessitating the use of content analysis to reduce the ambiguity of the results and enhance the depth of understanding.

\subsection{Results of Content Analysis}

3.2.1. Research Topics. The sample size for content analysis was 108 because two studies included multicategory analyses $[47,54]$. As illustrated in Table 4, network studies in the construction domain predominantly emphasized interindividual and interorganizational relationships within a single project (34.26\% and $38.89 \%$, resp.). Interindividual relationships within in a single project (Category I) were the focus of the earliest network studies in the construction domain. Studies addressing interorganizational relationships in a single project (Category III) have been notably increasing since 2005. Corporate-level studies (Category II) and industry-level studies (Category IV) examining relationships across projects began to appear after 2009.

A more substantive analysis of the contents was conducted, focusing on the specific types of network relations addressed in the 108 samples. Figure 5 visualizes the distribution of the publications by types of network relations and categories of network analysis. The colors in Figure 5 show whether the study was conducted in a static or dynamic view. The percentages are based on the sample size. It is important to note that this study did not differentiate between information exchange relation and knowledge exchange relation as these two relations were integrated in some studies. As shown in Figure 5, communication, information, and knowledge exchange, as well as collaboration networks, attracted the most scholarly interest, accounting for $29.63 \%, 44.44 \%$, and $21.30 \%$ of the identified studies, respectively. This result is in line with the conclusions drawn from keyword cooccurrence analysis. Some studies also investigated other types of relationships, such as contractual (11.11\%), advice (3.03\%), trust (4.04\%), influence $(2.02 \%)$, 
TABLE 3: A categorization framework of network research in construction.

\begin{tabular}{lccc}
\hline Type of network node & Intraproject level & Level of network analysis & Interproject level \\
Corporate level & Industry level \\
\hline $\begin{array}{l}\text { Interindividual } \\
\text { relations }\end{array}$ & $\begin{array}{c}\text { Category I: interindividual } \\
\text { networks in a single project }\end{array}$ & $\begin{array}{c}\text { Category II: interindividual } \\
\text { networks across projects at the } \\
\text { corporate level }\end{array}$ & - \\
$\begin{array}{l}\text { Interorganizational } \\
\text { relations }\end{array}$ & $\begin{array}{c}\text { Category III: interorganizational } \\
\text { networks in a single project }\end{array}$ & - & $\begin{array}{c}\text { Category IV: interorganizational } \\
\text { networks across projects at the industry } \\
\text { level }\end{array}$ \\
\hline
\end{tabular}

TABLe 4: Distribution of publications by period and categories of network analysis.

\begin{tabular}{lccccccc}
\hline & $1997-2000$ & $2001-2004$ & $2005-2008$ & $2009-2012$ & $2013-2016$ & $2017-2020$ & Total \\
\hline Category I & 4 & 2 & 2 & 6 & 4 & 6 & 37 \\
Category II & 0 & 0 & 0 & 2 & 8 & 11 & 6 \\
Category III & 0 & 0 & 0 & 3 & 3 & 21 \\
Category IV & 0 & 0 & 4 & 21 & 29 & 7 \\
Total & 4 & 2 & & 21 & 48 & 13 \\
\hline
\end{tabular}

Note: the sample size for content analysis is 108 as two studies include multicategory analyses $[47,54]$.

and spatial proximity $(3.03 \%)$ relations. Contractual relations were investigated as formal relationships $[7,48,55]$ and were mostly addressed for improving the efficiency of project governance $[49,50,56]$. Other nonofficial relations such as advice, trust, and influence relations were analyzed to better facilitate technical knowledge synergy [57], interface management [58], performance improvement $[59,60]$, and stakeholder management [61, 62]. Spatial proximity relations were examined for reducing task variation and improving work plan reliability $[63,64]$. Other relations, such as personal confidence, interpersonal friendship, sharing willingness, supply, interface, transaction, and strategic relations, received scant academic attention [56, 58, 60, 65-67]. Ten of the 26 longitudinal studies explored dynamic collaborative networks; several studies discussed the evolution of interpersonal communication relationships (7.41\%) as well as information and knowledge exchange relationships (2.78\%).

A summary of the literature distribution by categories of network analysis and types of network relations is listed in Table 5, revealing the main foci in each category of network studies. The studies in Category I placed great emphasis on communication as well as information and knowledge exchange relations (17 and 16 of 37 studies in Category I, resp.). The vast majority of the studies in Category II discussed information and knowledge exchange relations (14 of 16 studies in Category II), which indicates that knowledge management attracted the most scholarly interest in corporate-level research. The studies in Category III explored various types of network relations, such as contractual, trust, influence, spatial proximity, interface, and supply networks. The bulk of the studies in Category IV focused on collaboration networks ( 11 of 13 studies in Category IV). Five of these 11 studies were published after 2015 and were conducted longitudinally, suggesting that the dynamic characteristics of interorganizational collaboration have attracted increasing attention.
3.2.2. Research Designs. The specification of network boundaries and the collection of network data are at central roles in the design of network studies since the exclusion or omission of pertinent relations can result in distorted results [146]. According to Butts [147], network boundaries are most frequently set in three different ways: exogenously defined, relationally defined, and methodologically defined. The exogenously defined represents specifying the network boundary based on the research task or researchers' concern. It is commonly used in small group studies due to the welldefined membership. The relationally defined represents specifying the network boundary through setting a focal unit and finding the relations connected with it. The network boundary can also be defined through the methodology adopted for network data collection, which includes specifying boundaries limited to actors that use the same medium (e.g., e-mail and Twitter) or restricted to special contacts (e.g., all ties connected ego and alter).

Table 6 shows the distribution of publications based on the boundary specification methods and categories of network analysis. The percentages were calculated based on the amount of each category. The exogenously defined method was the most frequently used in Categories I, II, and III, accounting for $67.57 \%, 62.50 \%$, and $83.33 \%$ in these categories, respectively. The relationally defined method was more frequently adopted in Category III (11.90\%). Two sampling methods, including snowball sampling $[56,118,125]$ and chain-referral sampling $[121,123]$, were used in these studies. Compared with Category III, the methodologically defined method was more frequently used in Categories I, II, and IV $(27.03 \%, 31.25 \%$, and $92.31 \%$, resp.). For these studies, network data were obtained from social media [143, 144], e-mail dataset $[74,75,79,112]$, design logs [129], ego-centric SNA surveys $[93,107,127]$, and online databases $[3,9,11$, $51-53,67,139,141]$.

The trends of the network data sources employed in the identified studies are shown in Figure 6. The bar graph 


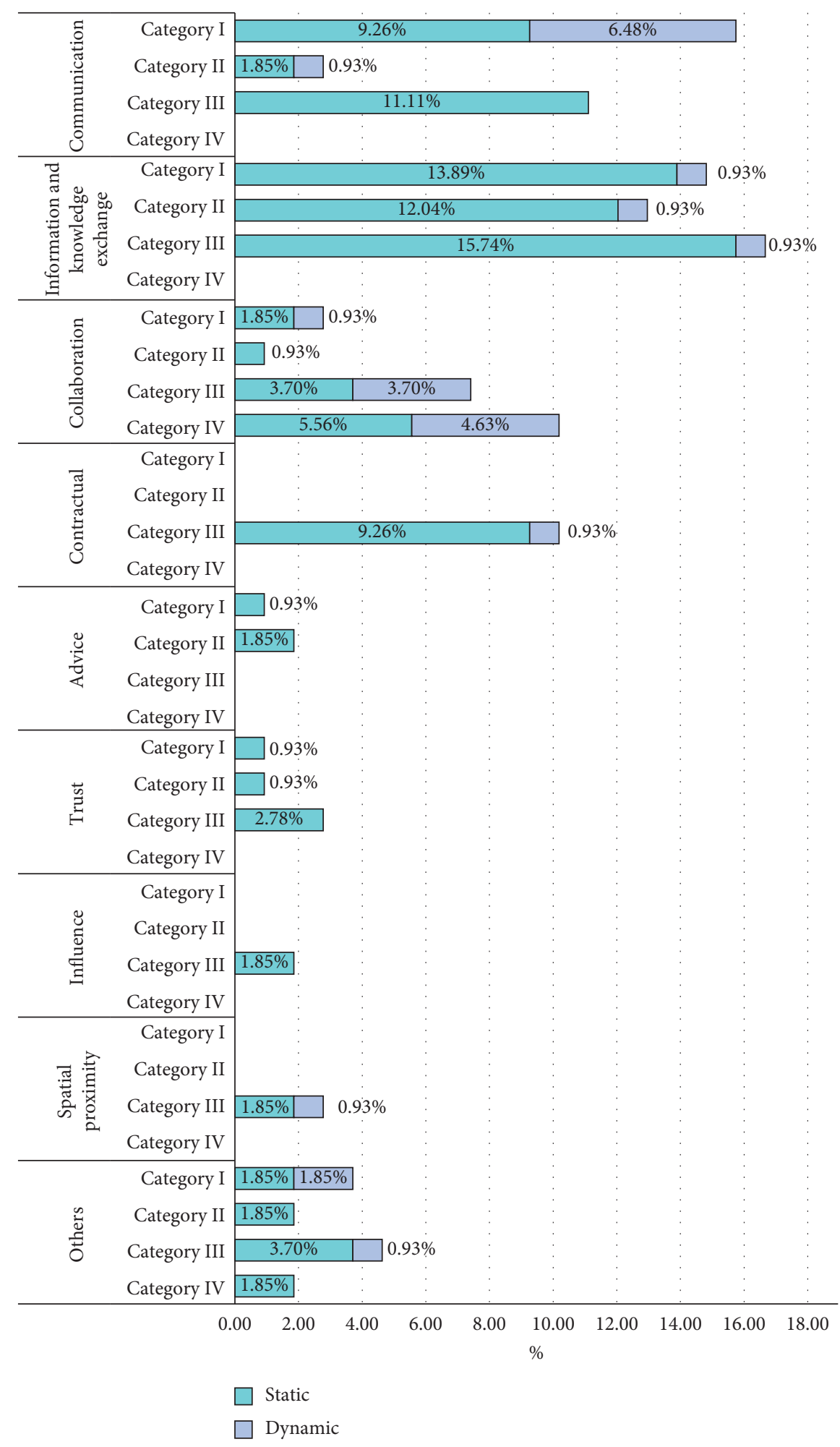

FIgURE 5: Distribution of publications by types of network relations.

depicts the absolute quantity of each data source, and the line graph represents the relative percentage (based on the total number of publications in each time slice). Surveys and interviews were the predominant data sources with a general downward trend. Mixed sources and online databases sources have gained increasing popularity since 2009.
Studies that collected data from other sources, such as site observation and work documents, have decreased since 2013. These results collectively indicate that more emphasis was placed on extracting data from databases and triangulating data from multiple sources because the network data collected from surveys and interviews is retrospective 
TABLE 5: Distribution of publications by types of network relations and categories of network analysis.

\begin{tabular}{|c|c|c|c|c|}
\hline $\begin{array}{l}\text { Types of network } \\
\text { relations }\end{array}$ & Category I & Category II & Category III & Category IV \\
\hline Communication & $\begin{array}{l}\text { Loosemore [19]; Loosemore } \\
\text { [69]; Loosemore [68]; } \\
\text { Loosemore [70]; Mead [71]; } \\
\text { Thorpe and Mead [72]; } \\
\text { Chinowsky et al. [73]; } \\
\text { Hossain [74]; Hossain [75]; } \\
\text { Hossain and Wu [47]; Di } \\
\text { Marco et al. [76]; } \\
\text { Ramalingam and } \\
\text { Mahalingam [77]; Liao et al. } \\
\text { [78]; Franz et al. [79]; } \\
\text { Herrera et al. [80]; Lu et al. } \\
\text { [81]; and Jafari et al. [54] }\end{array}$ & $\begin{array}{c}\text { Chinowsky et al. [82] } \\
\text { Chinowsky et al. [83]; and } \\
\text { Hossain and } \mathrm{Wu} \mathrm{[47]}\end{array}$ & $\begin{array}{c}\text { El-Sheikh and Pryke [48]; } \\
\text { Chinowsky et al. [84]; } \\
\text { Abbasian-Hosseini et al. [85]; } \\
\text { Dogan et al. [86]; Priven and } \\
\text { Sacks [87]; Priven and Sacks } \\
\text { [88]; Walters [89]; Zedan and } \\
\text { Miller [90]; Castillo et al. [60]; } \\
\text { Wang et al. [7]; Doloi [91]; and } \\
\text { Jafari et al. [54] }\end{array}$ & - \\
\hline $\begin{array}{l}\text { Information and } \\
\text { knowledge } \\
\text { exchange }\end{array}$ & $\begin{array}{l}\text { Iorio et al. [92]; Pauget and } \\
\text { Wald [93]; Di Marco et al. } \\
\text { [94]; Zhang et al. [95]; } \\
\text { Alsamadani et al. [96]; } \\
\text { Comu et al. [97]; } \\
\text { Alsamadani et al. [98]; } \\
\text { Lingard et al. [99]; Pirzadeh } \\
\text { and Lingard [100]; Allison } \\
\text { and Kaminsky [101]; } \\
\text { Schröpfer et al. [102]; Al } \\
\text { Hattab and Hamzeh [103]; } \\
\text { Pryke et al. [12]; Lingard } \\
\text { et al. [104]; Pandit et al. } \\
\text { [105]; and Herrera et al. [80] }\end{array}$ & $\begin{array}{c}\text { Chinowsky et al. [82]; Pryke } \\
\text { et al. [106]; Javernick-Will } \\
\text { [107]; Sanaei et al. [108]; Lin } \\
\text { and Tan [65]; Wanberg et al. } \\
\text { [109]; Wanberg et al. [110]; } \\
\text { Poleacovschi and Javernick- } \\
\text { Will [111]; Wen and Qiang } \\
\text { [112]; Poleacovschi et al. } \\
\text { [113]; Wanberg et al. [114]; } \\
\text { Castillo et al. [115]; } \\
\text { Chinowsky et al. [83]; and } \\
\text { Bonanomi et al. [116] }\end{array}$ & $\begin{array}{c}\text { Pryke [49]; Pryke and Pearson } \\
\text { [50]; Yang et al. [62]; } \\
\text { Chinowsky et al. [84]; Ruan } \\
\text { et al. [117]; Heng and } \\
\text { Loosemore [118]; Solis et al. } \\
\text { [59]; Yang [119]; Zhang et al. } \\
\text { [120]; Mok et al. [121]; } \\
\text { Papadonikolaki et al. [55]; } \\
\text { Park and Lee [122]; Mok et al. } \\
\text { [123]; Adami and Verschoore } \\
\text { [56]; Castillo et al. [60]; Adami } \\
\text { et al. [124]; Verschoore and } \\
\text { Adami [125]; and Mollaoglu- } \\
\text { Korkmaz et al. [126] }\end{array}$ & - \\
\hline Collaboration & $\begin{array}{l}\text { Koops et al. [127]; Wen et al. } \\
\text { [128]; and Herrera et al. [80] }\end{array}$ & Zhang and Ashuri [129] & $\begin{array}{l}\text { Li et al. [130]; Chowdhury } \\
\text { et al. [131]; Opdyke et al. [132]; } \\
\text { Wen et al. [133]; Wang et al. } \\
\text { [134]; South et al. [135]; Gao } \\
\text { et al. [8]; and Wang et al. [136] }\end{array}$ & $\begin{array}{l}\text { Castro et al. [137]; Park } \\
\text { et al. [138]; Liu et al. } \\
\text { [139]; Sedita and Apa } \\
\text { [140]; Lee et al. [9]; Cao } \\
\text { et al. [3]; Cao et al. [51]; } \\
\text { Tang et al. [11]; Han } \\
\text { et al. [52]; Li et al. [53]; } \\
\text { and Guevara et al. [141] }\end{array}$ \\
\hline Contractual & - & 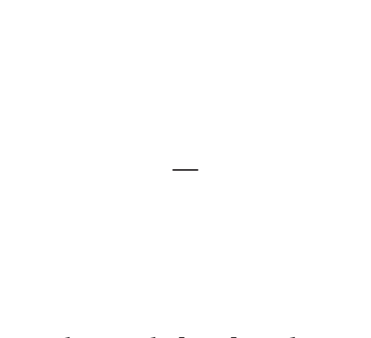 & $\begin{array}{c}\text { Pryke [49]; Pryke and Pearson } \\
\text { [50]; El-Sheikh and Pryke [48]; } \\
\text { Li et al. [130]; Papadonikolaki } \\
\text { et al. [55]; Adami and } \\
\text { Verschoore [56]; Wang et al. } \\
\text { [134]; Wang, et al. [136]; South } \\
\text { et al. [135]; Adami et al. [124]; } \\
\text { and Verschoore and Adami } \\
\text { [125] }\end{array}$ & - \\
\hline Advice & Lin [57] & $\begin{array}{l}\text { Pryke et al. [106] and Lin } \\
\text { and Tan [65] }\end{array}$ & - & - \\
\hline Trust & Herrera et al. [80] & Lin and Tan [65] & $\begin{array}{l}\text { Solis et al. [59]; Shen et al. [58]; } \\
\text { and Castillo et al. [115] }\end{array}$ & - \\
\hline Influence & - & - & $\begin{array}{c}\text { Yang et al. [61] and Yang et al. } \\
\text { [62]; } \\
\text { Wambeke et al. [63]; }\end{array}$ & - \\
\hline Spatial proximity & - & - & $\begin{array}{l}\text { Wambeke et al. [142]; and } \\
\text { Abbasian-Hosseini et al. [64] }\end{array}$ & - \\
\hline Others & $\begin{array}{l}\text { Williams et al. [143]; Lin } \\
\text { [57]; Nik-Bakht and El- } \\
\text { Diraby [144]; and Herrera } \\
\text { et al. [80] }\end{array}$ & $\begin{array}{l}\text { Lin and Tan [65] and } \\
\text { Castillo et al. [115] }\end{array}$ & $\begin{array}{l}\text { Pryke [49]; Pryke and Pearson } \\
\text { [50]; Shen et al. [58]; Adami } \\
\text { and Verschoore [56]; and Xue } \\
\text { et al. [145] }\end{array}$ & $\begin{array}{c}\text { Comet [66] and De } \\
\text { Biasio and Murray [67] }\end{array}$ \\
\hline
\end{tabular}


TABLE 6: Distribution of publications by boundary specification methods and categories of network analysis.

\begin{tabular}{lcccc}
\hline & Category I & Category II & Category III & Category IV \\
\hline Exogenously defined & $25(67.57 \%)$ & $10(62.50 \%)$ & $35(83.33 \%)$ & $1(7.69 \%)$ \\
Relationally defined & $2(5.41 \%)$ & $1(6.25 \%)$ & $5(11.90 \%)$ & $0(0.00 \%)$ \\
Methodologically defined & $10(27.03 \%)$ & $5(31.25 \%)$ & $2(4.76 \%)$ & $12(92.31 \%)$ \\
\hline
\end{tabular}

Note: percentages are based on the amount of publications in each category.

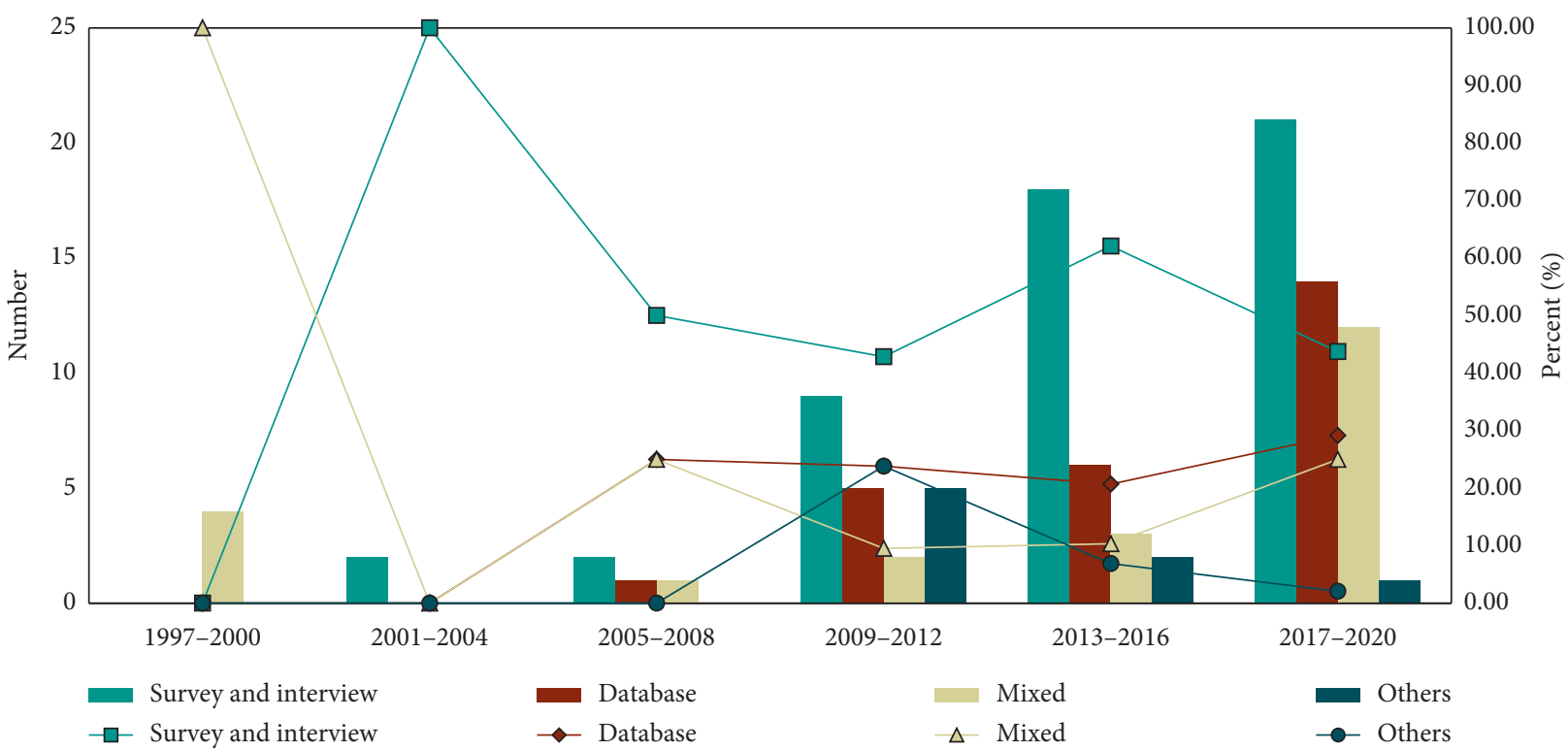

Figure 6: Trends in data sources across years (1997-2020).

and subjective in nature, and a single-source method might lack reliability and generate potential response biases.

To further quantitatively compare different data sources used in each category, the distribution of publications based on data sources and categories of network analysis is reported in Table 7. Surveys and interviews were the most frequently used sources to study project-level and corporatelevel relations (accounting for $48.65 \%, 47.62 \%$, and $81.25 \%$ in Categories I, III, and II, resp.). Among these studies, name generators and fixed name rosters were the most commonly used instruments to collect interindividual network data. For most interorganizational research, surveys and interviews were conducted among representative individuals to report on their organizational ties. However, such ties may be prone to involving a person's activities. Future research can be devoted to combining reports by multiple representative persons to determine organizational ties [115]. Interestingly, Table 7 also shows that, compared with interproject level research, intraproject level studies paid more attention to data triangulation (mixed sources accounted for $18.92 \%$ and $35.71 \%$ in Categories I and III, resp.).

3.2.3. Research Instruments. Multiple network constructs can be used to investigate the structural characteristics of a network. As indicated in previous studies [40, 42], the network constructs can be divided into three different levels (node, dyad, and network level). Considering that the dyadlevel constructs are less frequently used, this study only coded most frequently employed constructs in the node and network levels, as shown in Table 8. The node-level constructs enable researchers to depict an actor's position within a network. Among the node-level variables, degree centrality was the most frequently employed construct in each category. Betweenness centrality and closeness centrality were also frequently adopted, especially in Category I. However, structural hole was less used in interindividual level studies than in interorganizational level studies. This may result from the characteristics of construction projects; organizations within a temporary project are more fragmented with the disparate perception of stakeholders towards objectives [118]. Thus, researchers were motivated to investigate the structural holes to facilitate organizational communication and coordination $[56,118,125]$. Structural equivalence measures the competitiveness of a relationship while it was rarely used in the selected studies. Loosemore [19] found the concept of structural equivalence useful to investigate communication efficiency. Studies in other related fields suggest that actor's adoption decision towards new technologies can be affected through structural equivalence $[41,148,149]$. Future research in the construction domain can leverage structural equivalence to better disentangle how social contagion influences the diffusion of innovative technologies (e.g., BIM) among industry organizations and professionals. Network-level constructs capture the overall compactness and distributions of relations in the whole network. The most frequently used construct in the network level was network density. Nonetheless, network cohesion and degree distribution were 
TABLE 7: Distribution of publications by data sources and categories of network analysis.

\begin{tabular}{|c|c|c|c|c|}
\hline & Category I & Category II & Category III & Category IV \\
\hline Surveys and interviews & $18(48.65 \%)$ & $13(81.25 \%)$ & $20(47.62 \%)$ & $1(7.69 \%)$ \\
\hline Databases & $8(21.62 \%)$ & $3(18.75 \%)$ & $3(7.14 \%)$ & $12(92.31 \%)$ \\
\hline Mixed & $7(18.92 \%)$ & $0(0.00 \%)$ & $15(35.71 \%)$ & $0(0.00 \%)$ \\
\hline Others & $4(10.81 \%)$ & $0(0.00 \%)$ & $4(9.52 \%)$ & $0(0.00 \%)$ \\
\hline
\end{tabular}

Note: percentages are based on the amount of publications in each category.

TABLE 8: Distribution of publications by SNA constructs and categories of network analysis.

\begin{tabular}{|c|c|c|c|c|c|c|c|c|c|}
\hline & \multicolumn{6}{|c|}{ Node level } & \multicolumn{3}{|c|}{ Network level } \\
\hline & $\begin{array}{c}\text { Degree } \\
\text { centrality }\end{array}$ & $\begin{array}{c}\text { Betweenness } \\
\text { centrality }\end{array}$ & $\begin{array}{l}\text { Closeness } \\
\text { centrality }\end{array}$ & $\begin{array}{c}\text { Eigenvector } \\
\text { centrality }\end{array}$ & $\begin{array}{l}\text { Structural } \\
\text { hole }\end{array}$ & $\begin{array}{c}\text { Structural } \\
\text { equivalence }\end{array}$ & $\begin{array}{l}\text { Network } \\
\text { density }\end{array}$ & $\begin{array}{l}\text { Network } \\
\text { cohesion }\end{array}$ & $\begin{array}{c}\text { Power-law } \\
\text { degree } \\
\text { distribution }\end{array}$ \\
\hline Category I & $30(81.08 \%)$ & $25(67.57 \%)$ & $13(35.14 \%)$ & $3(8.11 \%)$ & $1(2.70 \%)$ & $4(10.81 \%)$ & $19(51.35 \%)$ & $2(5.41 \%)$ & $1(2.70 \%)$ \\
\hline Category II & $4(25.00 \%)$ & 3 (18.75\%) & $4(25.00 \%)$ & $0(0.00 \%)$ & $0(0.00 \%)$ & $0(0.00 \%)$ & $4(25.00 \%)$ & $1(6.25 \%)$ & $0(0.00 \%)$ \\
\hline Category III & $29(69.05 \%)$ & $16(38.10 \%)$ & $11(26.19 \%)$ & 7 (16.67\%) & $3(7.14 \%)$ & $1(2.38 \%)$ & $19(45.24 \%)$ & $\begin{array}{c}5 \\
(11.90 \%)\end{array}$ & $0(0.00 \%)$ \\
\hline Category IV & $10(76.92 \%)$ & $5(38.46 \%)$ & $5(38.46 \%)$ & $3(23.08 \%)$ & $1(7.69 \%)$ & $1(7.69 \%)$ & 7 (53.85\%) & $1(7.69 \%)$ & $5(38.46 \%)$ \\
\hline
\end{tabular}

Note: percentages are based on the amount of publications in each category.

less adopted. Compared with intraproject level and corporate-level studies, industry-level studies $(38.46 \%)$ used degree distribution mostly for unveiling the uneven distribution of interproject collaborations $[3,9,11,53,139]$.

The quantitative analysis methods can be summarized into five categories, including descriptive analysis, correlation analysis, regression analysis, and simulation. Descriptive analysis was adopted to summarize the basic network characteristics. Correlation and linear regression analysis were used to uncover the relationships between network constructs and safety climate $[78,104,105]$, project performance $[7,60,115]$, management efficiency [69], individual performance $[111,129]$, company's profit [66], organizational competitiveness [51], and individual coordination $[74,75,86]$. However, considering that social actors are embedded within the social environment [150], the observed correlation in linear regression analyses may result from the inherently interdependent nature of social relations [151]. To address this methodological gap, several simulation methods were introduced in the construction domain, including the quadratic assignment procedure (QAP) $[9,113,137]$, the exponential random graph model (ERGM) $[97,109]$, and the stochastic actor-based model (SAOM) $[3,11,53]$.

Based on the permutations test that repeated a considerable number of times, the QAP is a promising statistical method to control for dependence among variables [151]. As a stochastic rather than a deterministic approach, the EGRM treats the links of a network as endogenous and random [152]. The hypothesis embodied in the EGRM is based on dyadic dependence, which permits possible homophily effects among actors [152]. The SAOM can be regarded as an actor-oriented simulation model in which actors evaluate the network structure and change their outgoing ties for myopically optimizing an objective function [153]. While these three simulation models have considered the interdependence of social relations, the detailed differences need to be pointed out. First, both the QAP and the ERGM can be applied to cross-sectional data while the SAOM can be used for analyzing longitudinal data [154]. Second, the QAP does not allow the specification of endogenous effects (structurebased effects); only the EGRM and the SAOM do [155]. Apart from these, the SAOM can also model the coevolution of both networks and behaviors [156].

The trends of these quantitative analysis methods are displayed in Figure 7. The bar graph depicts the absolute quantity of each method, and the line graph represents the relative percentage (based on the total number of publications in each time slice). The bulk of SNA-based studies only conducted descriptive analyses, analyzing the visual sociogram or calculating several network constructs. It suggests that network research in the construction domain has been a relatively immature field receiving most attention paid to understand the network structures among organizations or individuals. It is worth noting that the relative percentage of descriptive analysis has decreased since 2013 together with the increase of correlation analysis, regression analysis, simulation, and other methods (e.g., structural equation modeling (SEM), data envelopment analysis (DEA), and semantic analysis). The distribution of publications by quantitative analysis methods and categories of network analysis is further reported in Table 9. The majority of studies in Categories I and III only employed descriptive analysis (54.05\% and $76.19 \%$, resp.) while many studies in Categories II and IV adopted inferential statistics, especially simulation analysis (18.75\% and $38.46 \%$, resp.). This implies that project-level studies mostly focused on revealing how the networks are arranged and who the influential actors are. 


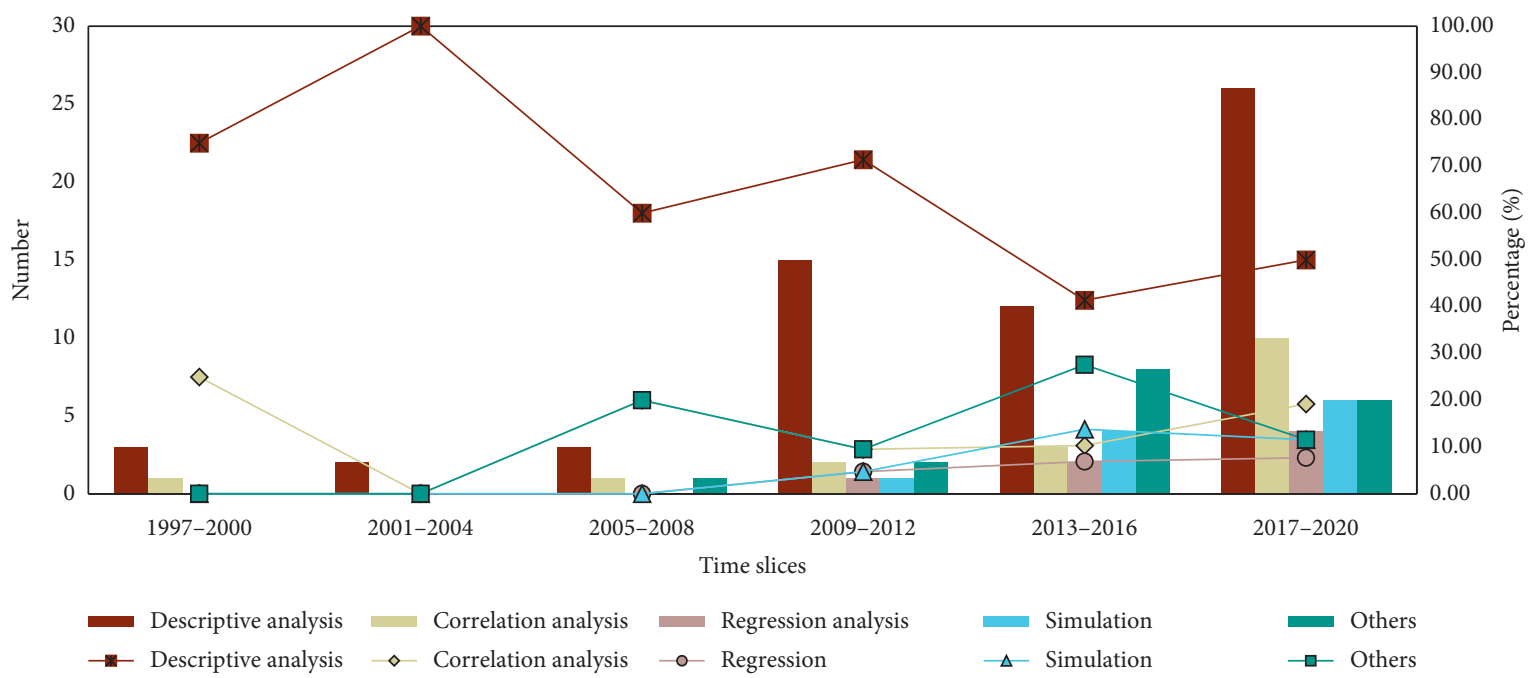

FIGURE 7: Trends in quantitative analysis methods across years (1997-2020).

TABLE 9: Distribution of publications by quantitative analysis methods and categories of network analysis.

\begin{tabular}{lcccc}
\hline & Category I & Category II & Category III & Category IV \\
\hline Descriptive analysis & $20(54.05 \%)$ & $6(37.50 \%)$ & $32(76.19 \%)$ & $3(23.08 \%)$ \\
Correlation analysis & $7(18.92 \%)$ & $3(18.75 \%)$ & $5(11.90 \%)$ & $2(15.38 \%)$ \\
Regression analysis & $3(8.11 \%)$ & $3(6.25 \%)$ & $0(0.00 \%)$ & $3(23.08 \%)$ \\
Simulation analysis & $2(5.41 \%)$ & $3(18.75 \%)$ & $1(2.38 \%)$ & $5(38.46 \%)$ \\
Others & $8(21.62 \%)$ & $5(11.90 \%)$ & $1(7.69 \%)$ \\
\hline
\end{tabular}

Note: percentages are based on the amount of publications in each category.

However, corporate-level and industry-level studies mostly further explored the relationships between network structures and actors' behaviors as well as project outcomes.

\section{Discussion and Future Research Directions}

4.1. Discussion of Findings. Through combining bibliometric analysis and content analysis, this study identified the research trends and developed an integrated framework for previous SNA-based studies, which enabled deeper and more systematic insights into the research topics, research designs, and research instruments of network studies in the construction domain. The findings of bibliometric analysis indicate that research keywords of the reviewed literature are generally veering away from a static focus to a more dynamic perspective. The results of content analysis further illustrate that increasing scholarly interests have been attracted to examine more macronetworks such as interproject relationships and most of these studies were conducted longitudinally. Taken together, these results tend to suggest that the research foci of network studies in the construction domain are generally moving towards addressing the complexity and dynamics of project-related relations at more diversified levels. A plausible explanation for this trend is that, with the evolution of organizational and process paradigms in the construction industry, it is increasingly recognized that the performance of construction activities is not only impacted by the relationships within corresponding projects at the short term but also shaped by how individuals and organizations interact with each other across projects in the long term [51]. The development of construction-related databases and data analytics also enables researchers to conduct related analyses from more macro- and dynamic perspectives.

Another noteworthy finding of this study is that, compared with corporate-level and industry-level studies, the vast majority of project-level studies only conducted descriptive analyses to characterize the characteristics of relation networks among project stakeholders but infrequently employed inferential statistics to further explore the associations between network structures and organizational behaviors as well as project outcomes. One plausible explanation for this finding might be that project-level networks are generally more stable than industry-level and corporate-level networks in nature [3]. As a result, projectlevel studies tend to focus more on the structure of the networks in which stakeholders are embedded. In contrast, a critical point of departure for corporate-level and industrylevel studies is to improve organizational competitiveness or the performance of the construction industry. Thus, this stream of network studies generally pays more attention on whether and how the behaviors and outcomes of construction organizations impact or are impacted by their relationship networks $[3,51]$. Another plausible explanation can be that corporate-level and industry-level network data, which can be retrieved from public databases in many cases, might be more easily collected as compared with projectlevel network data which are generally obtained through 


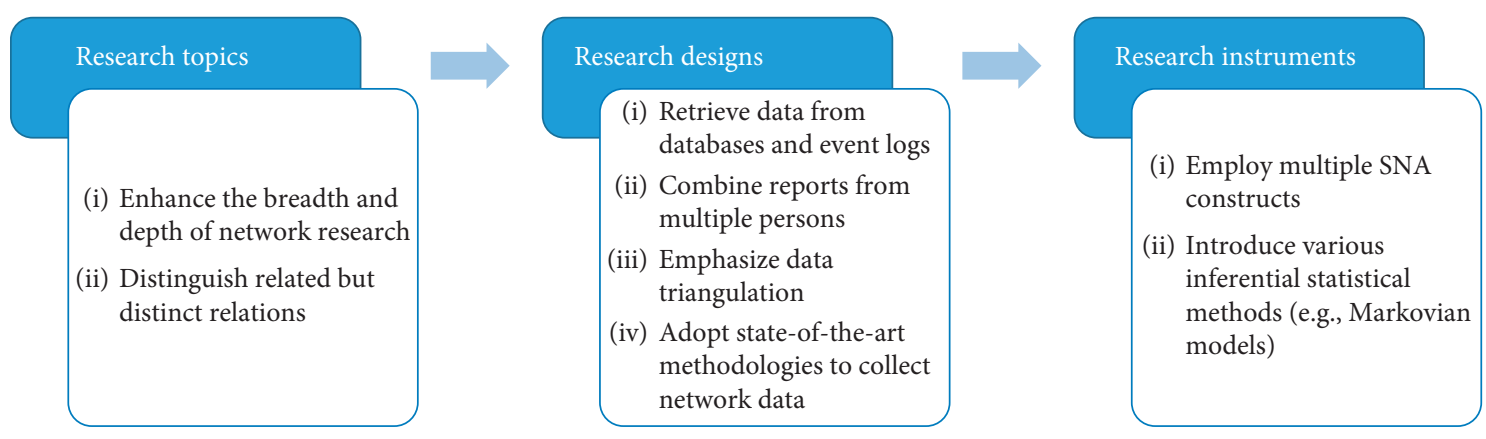

FIGURE 8: Future directions for network research in construction.

survey and interview. Nevertheless, the debates over how individuals shape the networks within which they are embedded and how these networks influence individuals' characters and performance have been at the heart of organizational social network research $[18,157]$. These results tend to suggest that more efforts need to be paid in projectlevel studies to deepen our understandings of how relationship networks within construction projects interact with related organizational or project behaviors and outcomes.

4.2. Future Research Directions. Previous review studies have suggested several potential directions from the perspectives of SNA constructs [6] and stakeholder management [17] for future network research in the project organization domain and the complex project management domain. However, considering the multiplex levels and manifold relation types of networks in the construction domain, it would be significant to further discuss the limitations of extant studies and the directions for future research based on a more systemic perspective. As shown in Figure 8, future research can be enriched from the perspectives of research topics, research designs, and research instruments. Regarding the lack of corporate- and industry-level research, as well as longitudinal network research, future research can investigate multiple types of dynamic interproject relationships, such as advice, trust, and influence relations, as shown in Figure 5. Previous scholars have also suggested future studies to conduct longitudinal research to better reveal how different relationship networks evolve within a project or across projects over time [16]. Another gap is that a paucity of studies has clearly distinguished related but distinct relations; for instance, communication, information exchange, and knowledge exchange relations are easily confused with each other. As suggested by Chinowsky et al. [73], communication is a more general interaction among actors while information exchange specifies related tasks and knowledge exchange emphasizes why tasks are done in this way and how to achieve higher performances. Considering the difficulties for interviewees to distinguish the differences among several relations, researchers can explore well-defined relations by specifying the situations.

Concerning research designs, more attention should be paid to network boundary specification and network data triangulation to conduct compelling studies. However, as mentioned in previous studies, the boundary of a network is often difficult to effectively identify. Retrieving data from online databases and mining data from event logs can serve as promising alternative sources because methodologically defining the network boundary is more objective and scientific. Considering that investigating interorganizational relations through surveys and interviews is prone to involving an individual's activities, future research can combine reports by multiple representative persons for determining organizational ties [115]. In viewing the difficulty in data triangulation, some state-of-the-art methodologies, such as wearable sensors and emotional facial recognition, can be employed [40]. These methods could help to collect other types of objective relationship data and can thus have a potential to be combined with surveys or archives for data triangulation.

Given that the use of SNA is still in its infancy in the construction domain, additional efforts are needed to leverage multiple SNA constructs [6] and inferential statistical methods to capture the complexity and dynamics of construction projects. Many of the identified SNA studies, especially corporate-level research, do not fully use SNA constructs to unravel the underlying complexity of construction projects. For instance, structural equivalence can be used to better disentangle how social contagion influences the diffusion of innovative technologies (e.g., BIM) $[41,148,149]$; however, this is less used in the identified studies. As discussed earlier, project-level studies mostly focused on depicting the networks while corporate-level and industry-level studies explored the relationships between network structures and actors' behaviors as well as project outcomes. Thus, future SNA-based research, especially for project-level studies, needs to focus on leveraging various inferential statistical methods to explore how individuals shape the project networks in which they are embedded and how these networks influence organizational or individual behaviors and project performance [17], which have attracted great interests in organizational social network research [157]. For example, Markovian models yield new insights into analyzing longitudinal data and examining how social networks can coevolve and interact with actors' behaviors [42]. These models may extend our knowledge on how various types of interindividual or interorganizational networks can associate with innovation implementation behaviors from a longitudinal view $[3,51,55,158,159]$. 


\section{Conclusions}

As an attempt to develop an integrated framework for SNAbased studies at different levels related to construction activities, this study is the first of its kind to conduct a bibliometric-qualitative review that systematically maps and critically identifies the research topics, research designs, and research instruments of different categories of network research in the construction domain. Based on a three-stage data retrieval process, 106 papers were identified from nine top-ranked and qualified journals. The results of keyword cooccurrence analysis revealed the research foci and enlightened the research trends of SNA-based research in the construction domain. The findings indicated that the research foci in the construction domain are generally moving towards characterizing and addressing the complexity and dynamics of interproject relations. Also, the results of bibliometric analysis provided an intriguing insight that SNA-based research conducted in the construction domain can be placed into a categorization framework with two dimensions, including the type of network node and the level of network analysis.

Content analysis was carried out in terms of research topics, research designs, and research instruments based on the integrated categorization framework. The results of content analysis revealed that corporate- and industry-level research did not receive much attention compared to project-level research. Through reviewing the boundary specification methods and data sources, this study contributes to deepened understandings of how SNA was used in the construction domain. The results revealed that the exogenously defined method was widely used in the identified studies (except for industry-level research). Although surveys and interviews were the predominant data sources, mixed sources and databases have gained increasing popularity in recent years. Several novel insights also came to light by reviewing the research instruments of the selected studies. The results indicated that network research in the construction domain is still at an infant stage, with the vast majority of the investigations still primarily focusing on descriptively analyzing the structural characteristics of related networks. By contrast, scant attention has been paid to further characterize the dynamics and influences of the network structures using inferential statistical or simulation methods.

Compared with previous studies that focus on characterizing the application of SNA in construction research in specific domains such as project organization or complex project management, this study developed an integrated framework for the network research in the construction domain at project, corporate, and industry levels and provided future research suggestions from the perspectives of research topics, research designs, and research instruments. In the future, attention should be paid to enhance the breadth and depth of network research in the construction domain by investigating multiple types of dynamic interproject relations. By specifying the research situations, researchers can well distinguish related but distinct networks. Additionally, more attention should be given to methodologically defined boundary specification method and data triangulation with the help of online databases and state-of-the-art methodologies. It is also worth noting that multiple network constructs and Markovian models can create fertile opportunities for further research. Despite the promising findings and contributions of this study as discussed, this study is also subjected to the following limitations: first, it only included publications written in English. Future studies can extend to other languages; for instance, researchers can review the research interests and trends of Chinese publications and compare these with English language publications. Also, the identified 106 studies may not cover all relevant studies limited by problems such as diversity in terminology [31]. However, through conducting an additional manual search, the limitation of the database search can be mitigated. Besides, content analysis may be prone to cognitive biases. Nonetheless, this limitation can be mitigated through independently dual-coding and measuring the reliability of data collection.

\section{Data Availability}

The data used to support the findings of this study are available from the corresponding author upon request.

\section{Conflicts of Interest}

The authors declare that there are no conflicts of interest regarding the publication of this paper.

\section{Acknowledgments}

This work was supported by the National Natural Science Foundation of China (Grant number 71802150) and the Central University Basic Research Funding of China (Grant number 12002150055).

\section{References}

[1] A. Dubois and L.-E. Gadde, "The construction industry as a loosely coupled system: implications for productivity and innovation," Construction Management and Economics, vol. 20, no. 7, pp. 621-631, 2002.

[2] G. Winch, "The construction firm and the construction project: a transaction cost approach," Construction Management and Economics, vol. 7, no. 4, pp. 331-345, 1989.

[3] D. Cao, H. Li, G. Wang, X. Luo, X. Yang, and D. Tan, "Dynamics of project-based collaborative networks for BIM implementation: analysis based on stochastic actor-oriented models," Journal of Management in Engineering, vol. 33, no. 3, Article ID 04016055, 2017.

[4] L. S. Cardona-Meza and G. Olivar-Tost, "Modeling and simulation of project management through the $\mathrm{PMBOK}{ }^{\circledR}$ standard using complex networks," Complexity, vol. 2017, Article ID 4791635, 12 pages, 2017.

[5] Z. Li, X. Lv, H. Zhu, and Z. Sheng, "Analysis of complexity of unsafe behavior in construction teams and a multiagent simulation," Complexity, vol. 2018, Article ID 6568719, 15 pages, 2018.

[6] C. Y. Lee, H. Y. Chong, P. C. Liao, and X. Wang, "Critical review of social network analysis applications in complex 
project management," Journal of Management in Engineering, vol. 34, no. 2, Article ID 04017061, 2018.

[7] H. Wang, W. Lu, J. Söderlund, and K. Chen, "The interplay between formal and informal institutions in projects," Project Management Journal, vol. 49, no. 4, pp. 20-35, 2018.

[8] S. Gao, X. Song, and R. Ding, "Promoting information transfer in collaborative projects through network structure adjustment," Journal of Construction Engineering \& Management, vol. 146, no. 2, Article ID 04019108, 2020.

[9] Y. S. Lee, J. J. Kim, and T. S. Lee, "Topological competiveness based on social relationships in the Korean constructionmanagement industry," Journal of Construction Engineering \& Management, vol. 142, no. 11, 2016.

[10] J. E. Taylor and P. G. Bernstein, "Paradigm trajectories of building information modeling practice in project networks," Journal of Management in Engineering, vol. 25, no. 2, pp. 69-76, 2009.

[11] Y. Tang, G. Wang, H. Li, and D. Cao, "Dynamics of collaborative networks between contractors and subcontractors in the construction industry: evidence from national quality award projects in China," Journal of Construction Engineering \& Management, vol. 144, no. 9, Article ID 05018009, 2018.

[12] S. Pryke, S. Badi, H. Almadhoob, B. Soundararaj, and S. Addyman, "Self-organizing networks in complex infrastructure projects," Project Management Journal, vol. 49, no. 2, pp. 18-41, 2018.

[13] Z. Ding, W. Gong, S. Li, and Z. Wu, "System dynamics versus agent-based modeling: a review of complexity simulation in construction waste management," Sustainability, vol. 10, no. 7, p. 2484, 2018.

[14] M. Liu, Y. Le, Y. Hu, B. Xia, M. Skitmore, and X. Gao, "System dynamics modeling for construction management research: critical review and future trends," Journal of Civil Engineering and Management, vol. 25, no. 8, pp. 730-741, 2019.

[15] Z. Wu, K. Yang, X. Lai, and M. F. Antwi-Afari, "A scientometric review of system dynamics applications in construction management research," Sustainability, vol. 12, no. 18, p. $7474,2020$.

[16] P. Chinowsky and J. E. Taylor, "Networks in engineering: an emerging approach to project organization studies," Engineering Project Organization Journal, vol. 2, no. 1-2, pp. 15-26, 2012.

[17] X. Zheng, Y. Le, A. P. C. Chan, Y. Hu, and Y. Li, "Review of the application of social network analysis (SNA) in construction project management research," International Journal of Project Management, vol. 34, no. 7, pp. 1214-1225, 2016.

[18] A. Zaheer, R. Gözübüyük, and H. Milanov, "It's the connections: the network perspective in interorganizational research," Academy of Management Perspectives, vol. 24, no. 1, pp. 62-77, 2010.

[19] M. Loosemore, "Construction crises as periods of social adjustment," Journal of Management in Engineering, vol. 13, no. 4, pp. 30-37, 1997.

[20] A. Harden and J. Thomas, "Mixed methods and systematic reviews," in Sage Handbook of Mixed Methods in Social \& Behavioral Research, A. Tashakkori and C. Teddlie, Eds., Sage, Thousand Oaks, CA, USA, 2nd edition, 2010.

[21] M. Petticrew and H. Roberts, Systematic Reviews in the Social Sciences: A Practical Guide, Blackwell Publishing Ltd, Malden, MA, USA, 2008.
[22] Q. He, G. Wang, L. Luo, Q. Shi, J. Xie, and X. Meng, "Mapping the managerial areas of Building Information Modeling (BIM) using scientometric analysis," International Journal of Project Management, vol. 35, no. 4, pp. 670-685, May 2017.

[23] M. Oraee, M. R. Hosseini, E. Papadonikolaki, R. Palliyaguru, and M. Arashpour, "Collaboration in BIM-based construction networks: a bibliometric-qualitative literature review," International Journal of Project Management, vol. 35, no. 7, pp. 1288-1301, Oct. 2017.

[24] W. Yi and A. P. C. Chan, "Critical review of labor productivity research in construction journals," Journal of Management in Engineering, vol. 30, no. 2, pp. 214-225, 2014.

[25] M. A. Adabre and A. P. C. Chan, "The ends required to justify the means for sustainable affordable housing: a review on critical success criteria," Sustainable development, vol. 27, no. 4, pp. 781-794, 2019.

[26] A. Darko, A. P. C. Chan, M. A. Adabre, D. J. Edwards, M. R. Hosseini, and E. E. Ameyaw, "Artificial intelligence in the AEC industry: scientometric analysis and visualization of research activities," Automation in Construction, vol. 112, p. 103081, 2020.

[27] D. W. Aksnes and G. Sivertsen, "A criteria-based assessment of the coverage of Scopus and Web of science," Journal of Data and Information Science, vol. 4, no. 1, pp. 1-21, 2019.

[28] J. Steen, R. DeFillippi, J. Sydow, S. Pryke, and I. Michelfelder, "Projects and networks: understanding resource flows and governance of temporary organizations with quantitative and qualitative research methods," Project Management Journal, vol. 49, no. 2, pp. 3-17, 2018.

[29] A. P. Siddaway, A. M. Wood, and L. V. Hedges, "How to do a systematic review: a best practice guide for conducting and reporting narrative reviews, meta-analyses, and meta-syntheses," Annual Review of Psychology, vol. 70, no. 1, pp. 747-770, 2019.

[30] K. W. Chau, "The ranking of construction management journals," Construction Management and Economics, vol. 15, no. 4, pp. 387-398, 1997.

[31] M. B. Harari, H. R. Parola, C. J. Hartwell, and A. Riegelman, "Literature searches in systematic reviews and meta-analyses: a review, evaluation, and recommendations," Journal of Vocational Behavior, vol. 118, p. 103377, 2020.

[32] G. Albort-Morant and D. Ribeiro-Soriano, "A bibliometric analysis of international impact of business incubators," Journal of Business Research, vol. 69, no. 5, pp. 1775-1779, 2016.

[33] T. U. Daim, G. Rueda, H. Martin, and P. Gerdsri, "Forecasting emerging technologies: use of bibliometrics and patent analysis," Technological Forecasting and Social Change, vol. 73, no. 8, pp. 981-1012, 2006.

[34] M. J. Cobo, A. G. López-Herrera, E. Herrera-Viedma, and F. Herrera, "Science mapping software tools: review, analysis, and cooperative study among tools," Journal of the American Society for Information Science and Technology, vol. 62, no. 7, pp. 1382-1402, 2011.

[35] C. Chen, "CiteSpace II: detecting and visualizing emerging trends and transient patterns in scientific literature," Journal of the American Society for Information Science and Technology, vol. 64, pp. 1852-1863, 2006.

[36] V. J. Duriau, R. K. Reger, and M. D. Pfarrer, "A content analysis of the content analysis literature in organization studies: research themes, data sources, and methodological refinements," Organizational Research Methods, vol. 10, no. 1, pp. 5-34, 2007. 
[37] K. G. Provan, A. Fish, and J. Sydow, "Interorganizational networks at the network level: a review of the empirical literature on whole networks," Journal of Management, vol. 33, no. 3, pp. 479-516, 2007.

[38] L. C. Freeman, "Centrality in social networks conceptual clarification," Social Networks, vol. 1, no. 3, pp. 215-239, 1978.

[39] P. Bonacich, "Power and centrality: a family of measures," American Journal of Sociology, vol. 92, no. 5, pp. 1170-1182, 1987.

[40] S. Park, T. J. Grosser, A. A. Roebuck, and J. E. Mathieu, "Understanding work teams from a network perspective: a review and future research directions," Journal of Management, vol. 46, no. 6, 2020.

[41] R. S. Burt, "Social contagion and innovation: cohesion versus structural equivalence," American Journal of Sociology, vol. 92, no. 6, pp. 1287-1335, 1987.

[42] M. A. Carpenter, M. Li, and H. Jiang, "Social network research in organizational contexts," Journal of Management, vol. 38, no. 4, pp. 1328-1361, 2012.

[43] A.-L. Barabási and R. Albert, "Emergence of scaling in random networks," Science, vol. 286, no. 5439, pp. 509-512, 1999.

[44] J. Cohen, "A coefficient of agreement for nominal scales," Educational and Psychological Measurement, vol. 20, no. 1, pp. 37-46, 1960.

[45] K. A. Hallgren, "Computing inter-rater reliability for observational data: an overview and tutorial," Tutorials in Quantitative Methods for Psychology, vol. 8, no. 1, pp. 23-34, 2012.

[46] M. L. McHugh, "Interrater reliability: the kappa statistic," Biochemia Medica, vol. 22, no. 3, pp. 276-282, 2012.

[47] L. Hossain and A. Wu, "Communications network centrality correlates to organisational coordination," International Journal of Project Management, vol. 27, no. 8, pp. 795-811, 2009.

[48] A. El-Sheikh and S. D. Pryke, "Network gaps and project success," Construction Management and Economics, vol. 28, no. 12, pp. 1205-1217, 2010.

[49] S. D. Pryke, "Towards a social network theory of project governance," Construction Management and Economics, vol. 23, no. 9, pp. 927-939, 2005.

[50] S. Pryke and S. Pearson, "Project governance: case studies on financial incentives," Building Research \& Information, vol. 34, no. 6, pp. 534-545, 2006.

[51] D. Cao, H. Li, G. Wang, X. Luo, and D. Tan, "Relationship network structure and organizational competitiveness: evidence from BIM implementation practices in the construction industry," Journal of Management in Engineering, vol. 34, no. 3, Article ID 04018005, 2018.

[52] Y. Han, Y. Li, J. E. Taylor, and J. Zhong, "Characteristics and evolution of innovative collaboration networks in architecture, engineering, and construction: study of national prize-winning projects in China," Journal of Construction Engineering \& Management, vol. 144, no. 6, Article ID 04018038, 2018.

[53] X. Li, H. Li, D. Cao, Y. Tang, X. Luo, and G. Wang, "Modeling dynamics of project-based collaborative networks for BIM implementation in the construction industry: empirical study in Hong Kong," Journal of Construction Engineering \& Management, vol. 145, no. 12, Article ID 05019013, 2019.

[54] P. Jafari, E. Mohamed, S. Lee, and S. Abourizk, "Social network analysis of change management processes for communication assessment," Automation in Construction, vol. 118, Article ID 103292, 2020.

[55] E. Papadonikolaki, A. Verbraeck, and H. Wamelink, "Formal and informal relations within BIM-enabled supply chain partnerships," Construction Management and Economics, vol. 35, no. 8-9, pp. 531-552, 2017.

[56] V. S. Adami and J. R. Verschoore, "Implications of network relations for the governance of complex projects," Project Management Journal, vol. 49, no. 2, pp. 71-88, 2018.

[57] S. C. Lin, "An analysis for construction engineering networks," Journal of Construction Engineering \& Management, vol. 141, no. 5, Article ID 04014096, 2015.

[58] W. Shen, W. Tang, S. Wang, C. F. Duffield, F. K. P. Hui, and R. You, "Enhancing trust-based interface management in international Engineering-Procurement-Construction projects," Journal of Construction Engineering \& Management, vol. 143, no. 9, Article ID 04017061, 2017.

[59] F. Solis, J. V. Sinfield, and D. M. Abraham, "Hybrid approach to the study of inter-organization high performance teams," Journal of Construction Engineering and Management, vol. 139, no. 4, pp. 379-392, 2013.

[60] T. Castillo, L. F. Alarcón, and J. L. Salvatierra, "Effects of last planner system practices on social networks and the performance of construction projects," Journal of Construction Engineering \& Management, vol. 144, no. 3, Article ID 04017120, 2018

[61] J. Yang, G. Q. Shen, M. Ho, D. S. Drew, and X. Xue, "Stakeholder management in construction: an empirical study to address research gaps in previous studies," International Journal of Project Management, vol. 29, no. 7, pp. 900-910, 2011.

[62] J. Yang, G. Q. Shen, L. Bourne, C. M. F. Ho, and X. Xue, “A typology of operational approaches for stakeholder analysis and engagement," Construction Management and Economics, vol. 29, no. 2, pp. 145-162, 2011.

[63] B. W. Wambeke, M. Liu, and S. M. Hsiang, "Task variation and the social network of construction trades," Journal of Management in Engineering, vol. 30, no. 4, Article ID 05014008, 2014.

[64] S. A. Abbasian-Hosseini, M. Liu, and S. M. Hsiang, "Social network conformity and construction work plan reliability," Automation in Construction, vol. 78, pp. 1-12, 2017.

[65] C.-L. Lin and H.-L. Tan, "Performance measurement in the public sector: example of the building administration authorities in Taiwan," Journal of Management in Engineering, vol. 30, no. 1, pp. 97-107, 2014.

[66] C. Comet, "Social capital and profits of small firms in the French construction industry," Construction Management and Economics, vol. 27, no. 4, pp. 411-418, 2009.

[67] A. De Biasio and A. Murray, "The social network of the UK PPP secondary equity market - returns and competition in an emerging market," Construction Management and Economics, vol. 35, no. 8-9, pp. 468-481, 2017.

[68] M. Loosemore, "Social network analysis: using a quantitative tool within an interpretative context to explore the management of construction crises," Engineering, Construction and Architectural Management, vol. 5, no. 4, pp. 315-326, 1998.

[69] M. Loosemore, "The influence of communication structure upon management efficiency," Construction Management and Economics, vol. 16, no. 6, pp. 661-671, 1998.

[70] M. Loosemore, "Responsibility, power and construction conflict," Construction Management and Economics, vol. 17, no. 6, pp. 699-709, 1999. 
[71] S. P. Mead, "Using social network analysis to visualize project teams," Project Management Journal, vol. 32, no. 4, pp. 32-38, 2001.

[72] T. Thorpe and S. Mead, "Project-specific Web sites: friend or foe?" Journal of Construction Engineering and Management, vol. 127, no. 5, pp. 406-413, 2001.

[73] P. Chinowsky, J. Diekmann, and V. Galotti, "Social network model of construction," Journal of Construction Engineering and Management, vol. 134, no. 10, pp. 804-812, 2008.

[74] L. Hossain, "Communications and coordination in construction projects," Construction Management and Economics, vol. 27, no. 1, pp. 25-39, 2008.

[75] L. Hossain, "Effect of organisational position and network centrality on project coordination," International Journal of Project Management, vol. 27, no. 7, pp. 680-689, 2009.

[76] M. K. Di Marco, J. E. Taylor, and P. Alin, "Emergence and role of cultural boundary spanners in global engineering project networks," Journal of Management in Engineering, vol. 26, no. 3, pp. 123-132, 2010.

[77] S. Ramalingam and A. Mahalingam, "Enabling conditions for the emergence and effective performance of technical and cultural boundary spanners in global virtual teams," Engineering Project Organization Journal, vol. 1, no. 2, pp. 121141, 2011.

[78] P. C. Liao, G. Lei, J. Xue, and D. Fang, "Influence of personorganizational fit on construction safety climate," Journal of Management in Engineering, vol. 31, no. 4, Article ID 04014049, 2015.

[79] B. Franz, R. Leicht, K. Maslak, and M. Rinker, "Framework for assessing resilience in the communication networks of AEC teams," Engineering Project Organization Journal, vol. 8, no. 1, 2018.

[80] R. F. Herrera, C. Mourgues, L. F. Alarcón, and E. Pellicer, "Understanding interactions between design team members of construction projects using social network analysis," Journal of Construction Engineering and Management, vol. 146, no. 6, Article ID 04020053, 2020.

[81] W. Lu, J. Xu, and J. Söderlund, "Exploring the effects of building information modeling on projects: longitudinal social network analysis," Journal of Construction Engineering \& Management, vol. 146, no. 5, Article ID 04020037, 2020.

[82] P. S. Chinowsky, J. Diekmann, and J. O'Brien, "Project organizations as social networks," Journal of Construction Engineering and Management, vol. 136, no. 4, pp. 452-458, 2010.

[83] P. S. Chinowsky, B. Robinson, and S. Robinson, "Analyzing the dynamics of social networks by combining psychometric measures with social network analysis," Engineering Project Organization Journal, vol. 8, no. 1, pp. 100-122, 2018.

[84] P. Chinowsky, J. E. Taylor, and M. Di Marco, "Project network interdependency alignment: new approach to assessing project effectiveness," Journal of Management in Engineering, vol. 27, no. 3, pp. 170-178, 2011.

[85] S. A. Abbasian-Hosseini, S. M. Hsiang, M. L. Leming, and M. Liu, "From social network to data envelopment analysis: identifying benchmarks at the site management level," Journal of Construction Engineering and Management, vol. 140, no. 8, Article ID 04014028, 2014.

[86] S. Z. Dogan, D. Arditi, S. Gunhan, and B. Erbasaranoglu, "Assessing coordination performance based on centrality in an e-mail communication network," Journal of Management in Engineering, vol. 31, no. 3, Article ID 0401404, 2015.

[87] V. Priven and R. Sacks, "Effects of the last planner system on social networks among construction trade crews," Journal of
Construction Engineering and Management, vol. 141, no. 6, Article ID 04015006, 2015.

[88] V. Priven and R. Sacks, "Impacts of the social subcontract and last planner system interventions on the trade-crew workflows of multistory residential construction projects," Journal of Construction Engineering \& Management, vol. 142, no. 7, Article ID 04016013, 2016.

[89] J. P. Walters, "Exploring the use of social network analysis to inform exit strategies for rural water and sanitation NGOs," Engineering Project Organization Journal, vol. 6, no. 2-4, 2016.

[90] S. Zedan and W. Miller, "Quantifying stakeholders' influence on energy efficiency of housing: development and application of a four-step methodology," Construction Management and Economics, vol. 36, no. 7, pp. 375-393, 2018.

[91] H. Doloi, "Community-centric model for evaluating social value in projects," Journal of Construction Engineering \& Management, vol. 144, no. 5, Article ID 04018019, 2018.

[92] J. Iorio, J. E. Taylor, and C. Sturts Dossick, “A bridge too far: examining the impact of facilitators on information transfer in global virtual project networks," Engineering Project Organization Journal, vol. 2, no. 4, pp. 188-201, 2012.

[93] B. Pauget and A. Wald, "Relational competence in complex temporary organizations: the case of a French hospital construction project network," International Journal of Project Management, vol. 31, no. 2, pp. 200-211, 2013.

[94] M. K. Di Marco, P. Alin, and J. E. Taylor, "Exploring negotiation through boundary objects in global design project networks," Project Management Journal, vol. 43, no. 3, pp. 24-39, 2012.

[95] L. Zhang, J. He, and S. Zhou, "Sharing tacit knowledge for integrated project team flexibility: case study of integrated project delivery," Journal of Construction Engineering and Management, vol. 139, no. 7, pp. 795-804, 2013.

[96] R. Alsamadani, M. R. Hallowell, A. Javernick-Will, and J. Cabello, "Relationships among language proficiency, communication patterns, and safety performance in small work crews in the United States," Journal of Construction Engineering and Management, vol. 139, no. 9, pp. 1125-1134, 2013.

[97] S. Comu, J. Iorio, J. E. Taylor, and C. S. Dossick, "Quantifying the impact of facilitation on transactive memory system formation in global virtual project networks," International Journal of Project Management, vol. 139, no. 3, pp. 294-303, 2013.

[98] R. Alsamadani, M. Hallowell, and A. N. Javernick-Will, "Measuring and modelling safety communication in small work crews in the US using social network analysis," Construction Management and Economics, vol. 31, no. 6, pp. 568-579, 2013.

[99] H. Lingard, P. Pirzadeh, N. Blismas, R. Wakefield, and B. Kleiner, "Exploring the link between early constructor involvement in project decision-making and the efficacy of health and safety risk control," Construction Management and Economics, vol. 32, no. 9, pp. 918-931, 2014.

[100] P. Pirzadeh and H. Lingard, "Understanding the dynamics of construction decision making and the impact on work health and safety," Journal of Management in Engineering, vol. 33, no. 5, Article ID 05017003, 2017.

[101] L. Allison and J. Kaminsky, "Safety communication networks: females in small work crews," Journal of Construction Engineering \& Management, vol. 143, no. 8, Article ID 04017050, 2017. 
[102] V. L. M. Schröpfer, J. Tah, and E. Kurul, "Mapping the knowledge flow in sustainable construction project teams using social network analysis," Engineering, Construction and Architectural Management, vol. 24, no. 2, pp. 229-259, 2017.

[103] M. Al Hattab and F. Hamzeh, "Simulating the dynamics of social agents and information flows in BIM-based design," Automation in Construction, vol. 92, pp. 1-22, 2018.

[104] H. Lingard, P. Pirzadeh, and D. Oswald, "Talking safety: health and safety communication and safety climate in subcontracted construction workgroups," Journal of Construction Engineering \& Management, vol. 145, no. 5, Article ID 04019029, 2019.

[105] B. Pandit, A. Albert, and Y. Patil, "Developing construction hazard recognition skill: leveraging safety climate and social network safety communication patterns," Construction Management and Economics, vol. 38, no. 7, pp. 640-658, 2020.

[106] S. D. Pryke, G. Zagkli, and I. Kougia, "Resource provision ego-networks in small Greek construction firms," Building Research \& Information, vol. 39, no. 6, pp. 616-636, 2011.

[107] A. Javernick-Will, "Knowledge-sharing connections across geographical boundaries in global intra-firm networks," Engineering Project Organization Journal, vol. 1, no. 4, pp. 239-253, 2011.

[108] M. Sanaei, A. N. Javernick-Will, and P. Chinowsky, "The influence of generation on knowledge sharing connections and methods in construction and engineering organizations headquartered in the US," Construction Management and Economics, vol. 31, no. 9, pp. 991-1004, 2013.

[109] J. Wanberg, A. Javernick-Will, J. E. Taylor, and P. Chinowsky, "The effects of organizational divisions on knowledge-sharing networks in multi-lateral communities of practice," Engineering Project Organization Journal, vol. 5, no. 2-3, pp. 118-132, 2015.

[110] J. Wanberg, A. Javernick-Will, P. Chinowsky, and J. E. Taylor, "Spanning cultural and geographic barriers with knowledge pipelines in multinational communities of practice," Journal of Construction Engineering \& Management, vol. 141, no. 4, 2015.

[111] C. Poleacovschi and A. Javernick-Will, "Spanning information and knowledge across subgroups and its effects on individual performance," Journal of Management in Engineering, vol. 32, no. 4, Article ID 04016006, 2016.

[112] Q. Wen and M. Qiang, "Coordination and knowledge sharing in construction project-based organization: a longitudinal structural equation model analysis," Automation in Construction, vol. 72, pp. 309-320, 2016.

[113] C. Poleacovschi, A. Javernick-Will, and T. Tong, "The link between knowledge sharing connections and employee time savings: a social network analysis," Construction Management and Economics, vol. 35, no. 8-9, pp. 455-467, 2017.

[114] J. Wanberg, A. Javernick-Will, and J. E. Taylor, "Mechanisms to initiate knowledge-sharing connections in communities of practice," Journal of Construction Engineering \& Management, vol. 143, no. 11, Article ID 04017085, 2017.

[115] T. Castillo, L. F. Alarcón, and E. Pellicer, "Influence of organizational characteristics on construction project performance using corporate social networks," Journal of Management in Engineering, vol. 34, no. 4, Article ID 04018013, 2018.

[116] M. M. Bonanomi, D. M. Hall, S. Staub-French, A. Tucker, C. M. L. Talamo, and C. M. L. Talamo, "The impact of digital transformation on formal and informal organizational structures of large architecture and engineering firms," Engineering, Construction and Architectural Management, vol. 27, no. 4, pp. 872-892, 2019.

[117] X. Ruan, E. G. Ochieng, A. D. F. Price, and C. O. Egbu, "Knowledge integration process in construction projects: a social network analysis approach to compare competitive and collaborative working," Construction Management and Economics, vol. 30, no. 1, pp. 5-19, 2012.

[118] H. K. S. Heng and M. Loosemore, "Structural holes in hospital organisations: facilities managers as intrapreneurial brokers in the tertiary health sector," Engineering, Construction and Architectural Management, vol. 20, no. 5, pp. 474-487, 2013.

[119] R. J. Yang, “An investigation of stakeholder analysis in urban development projects: empirical or rationalistic perspectives," International Journal of Project Management, vol. 32, no. 5, pp. 838-849, 2014.

[120] L. Zhang, J. Cheng, and W. Fan, "Party selection for integrated project delivery based on interorganizational transactive memory system," Journal of Construction Engineering \& Management, vol. 142, no. 3, Article ID 04015089, 2016.

[121] K. Y. Mok, G. Q. Shen, and R. Yang, "Stakeholder complexity in large scale green building projects a holistic analysis towards a better understanding," Engineering, Construction and Architectural Management, vol. 25, pp. 1454-1474, 2017.

[122] J. H. Park and G. Lee, "Design coordination strategies in a 2D and BIM mixed-project environment: social dynamics and productivity," Building Research \& Information, vol. 45, no. 6, pp. 631-648, 2017.

[123] K. Y. Mok, G. Q. Shen, and R. J. Yang, “Addressing stakeholder complexity and major pitfalls in large cultural building projects," International Journal of Project Management, vol. 35, no. 3, pp. 463-478, 2017.

[124] V. S. Adami, J. R. Verschoore, and J. A. V. Antunes Junior, "Effect of relational characteristics on management of wind farm interorganizational construction projects," Journal of Construction Engineering \& Management, vol. 145, no. 3, Article ID 05018019, 2019.

[125] J. R. Verschoore and V. S. Adami, "Interplay of competition and cooperation in wind farm interorganizational projects: relational approach," Journal of Management in Engineering, vol. 36, no. 1, Article ID 04019034, 2020.

[126] S. Mollaoglu-Korkmaz, V. D. Miller, and W. Sun, “Assessing key dimensions to effective innovation implementation in interorganizational project teams: an Integrated Project Delivery case," Engineering Project Organization Journal, vol. 4, no. 1, pp. 17-30, 2014.

[127] L. Koops, M. Bosch-Rekveldt, H. Bakker, and M. Hertogh, "Exploring the influence of external actors on the cooperation in public-private project organizations for constructing infrastructure," International Journal of Project Management, vol. 35, no. 4, pp. 618-632, 2017.

[128] Q. Wen, M. Qiang, and P. Gloor, "Speeding up decisionmaking in project environment: the effects of decision makers' collaboration network dynamics," International Journal of Project Management, vol. 36, no. 5, pp. 819-831, 2018.

[129] L. Zhang and B. Ashuri, "BIM log mining: discovering social networks," Automation in Construction, vol. 91, pp. 31-43, 2018.

[130] Y. Li, Y. Lu, Y. H. Kwak, Y. Le, and Q. He, "Social network analysis and organizational control in complex projects: construction of EXPO 2010 in China," Engineering Project Organization Journal, vol. 1, no. 4, pp. 223-237, 2011. 
[131] A. N. Chowdhury, P. H. Chen, and R. L. K. Tiong, “Analysing the structure of public-private partnership projects using network theory," Construction Management and Economics, vol. 29 , no. 3, pp. 247-260, 2011.

[132] A. Opdyke, F. Lepropre, A. Javernick-Will, and M. Koschmann, "Inter-organizational resource coordination in post-disaster infrastructure recovery," Construction Management and Economics, vol. 35, no. 8-9, pp. 514-530, 2017.

[133] Q. Wen, M. Qiang, and N. An, "Collaborating with construction management consultants in project execution: responsibility delegation and capability integration," Journal of Construction Engineering \& Management, vol. 143, no. 7, Article ID 04017021, 2017.

[134] H. Wang, X. Zhang, and W. Lu, "Improving social sustainability in construction: conceptual framework based on social network analysis," Journal of Management in Engineering, vol. 34, no. 6, Article ID 05018012, 2018.

[135] A. South, K. Eriksson, and R. Levitt, "How infrastructure public-private partnership projects change over project development phases," Project Management Journal, vol. 49, no. 4, pp. $62-80,2018$.

[136] Y. Wang, V. K. Thangasamy, Z. Hou, R. L. K. Tiong, and L. Zhang, "Collaborative relationship discovery in BIM project delivery: a social network analysis approach," $A u$ tomation in Construction, vol. 114, Article ID 103147, 2020.

[137] I. Castro, J. L. Galán, and C. Casanueva, "Antecedents of construction project coalitions: a study of the Spanish construction industry," Construction Management and Economics, vol. 27, no. 9, pp. 809-822, 2009.

[138] H. Park, S. H. Han, E. M. Rojas, J. Son, and W. Jung, "Social network analysis of collaborative ventures for overseas construction projects," Journal of Construction Engineering and Management, vol. 137, no. 5, pp. 344-355, 2011.

[139] L. Liu, C. Han, and W. Xu, "Evolutionary analysis of the collaboration networks within national quality award projects of China," International Journal of Project Management, vol. 33, no. 3, pp. 599-609, 2015.

[140] S. R. Sedita and R. Apa, "The impact of inter-organizational relationships on contractors' success in winning public procurement projects: the case of the construction industry in the Veneto region," International Journal of Project Management, vol. 33, no. 7, pp. 1548-1562, 2015.

[141] J. Guevara, J. Salazar, M. J. Garvin, and M. Asce, "Social network analysis of road PPP equity markets in Canada, Chile, and the United States," Journal of Management in Engineering, vol. 36, no. 5, Article ID 04020058, 2020.

[142] B. W. Wambeke, M. Liu, and S. M. Hsiang, "Using Pajek and centrality analysis to identify a social network of construction trades," Journal of Construction Engineering and Management, vol. 138, no. 10, pp. 1192-1201, 2012.

[143] N. L. Williams, N. Ferdinand, and B. Pasian, "Online stakeholder interactions in the early stage of a megaproject," Project Management Journal, vol. 46, no. 6, pp. 92-110, 2015.

[144] M. Nik-Bakht and T. El-Diraby, "Project collective mind: unlocking project discussion networks," Automation in Construction, vol. 84, pp. 50-69, 2017.

[145] J. Xue, G. Q. Shen, R. J. Yang, I. Zafar, and E. M. A. C. Ekanayake, "Dynamic network analysis of stakeholder conflicts in megaprojects: sixteen-year case of Hong Kong-Zhuhai-Macao bridge," Journal of Construction Engineering \& Management, vol. 146, no. 9, Article ID 04020103, 2020.
[146] P. V. Marsden, "Network data and measurement," Annual Review of Sociology, vol. 16, no. 1, pp. 435-463, 1990.

[147] C. T. Butts, "Social network analysis: a methodological introduction," Asian Journal Of Social Psychology, vol. 11, no. 1, pp. 13-41, 2008.

[148] X. Fang, P. J.-H. Hu, Z. Li, and W. Tsai, "Predicting adoption probabilities in social networks," Information Systems Research, vol. 24, no. 1, pp. 128-145, 2013.

[149] O. Hinz, C. Schulze, and C. Takac, "New product adoption in social networks: why direction matters," Journal of Business Research, vol. 67, no. 1, pp. 2836-2844, 2014.

[150] S. P. Borgatti, A. Mehra, D. J. Brass, and G. Labianca, "Network analysis in the social sciences," Science, vol. 323, no. 5916, pp. 892-895, 2009.

[151] D. Krackartd, "QAP partialling as a test of spuriosness," Social Networks, vol. 9, no. 2, pp. 171-186, 1987.

[152] G. Robins, P. Pattison, Y. Kalish, and D. Lusher, "An introduction to exponential random graph $(p *)$ models for social networks," Social Networks, vol. 29, no. 2, pp. 173-191, 2007.

[153] T. A. B. Snijders, "The statistical evaluation of social network dynamics," Sociological Methodology, vol. 31, no. 1, pp. 361-395, 2001.

[154] P. Block, C. Stadtfeld, and T. A. B. Snijders, "Forms of dependence: comparing SAOMs and ERGMs from basic principles," Sociological Methods \& Research, vol. 48, no. 1, pp. 202-239, 2019.

[155] S. J. Cranmer, P. Leifeld, S. D. McClurg, and M. Rolfe, "Navigating the range of statistical tools for inferential network analysis," American Journal of Political Science, vol. 61, no. 1, pp. 237-251, 2017

[156] T. A. B. Snijders, G. G. van de Bunt, and C. E. G. Steglich, "Introduction to stochastic actor-based models for network dynamics," Social Networks, vol. 32, no. 1, pp. 44-60, 2010.

[157] S. Tasselli, M. Kilduff, and J. I. Menges, "The microfoundations of organizational social networks," Journal of Management, vol. 41, no. 5, pp. 1361-1387, 2015.

[158] C. C. Phelps and H. Paris, "A longitudinal study of the influence of alliance network structure and composition on firm exploratory innovation," Academy of Management Journal, vol. 53, no. 4, pp. 890-913, 2010.

[159] X. Xue, X. Zhang, L. Wang, M. Skitmore, and Q. Wang, "Analyzing collaborative relationships among industrialized construction technology innovation organizations: a combined SNA and SEM approach," Journal of Cleaner Production, vol. 173, pp. 265-277, 2018. 